\title{
1981 Alaska Peninsula field program report
}

Billingsley, R.L., and Amoco Oil Co.

GMC DATA REPORT 462

This GMC data report from the Amoco Heritage collection has been made available through funding from the FY2018 USGS National Geological and Geophysical Data Preservation Program, Grant Number G18AP00054. This project report is presented in its original format and has not been reviewed for technical content or for conformity to the editorial standards of DGGS. It should not be used or cited as reviewed data.

2019

State of Alaska

Department of Natural Resources

Division of Geological \& Geophysical Surveys

GEOLOGIC MATERIALS CENTER
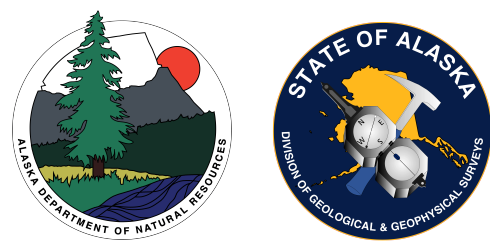


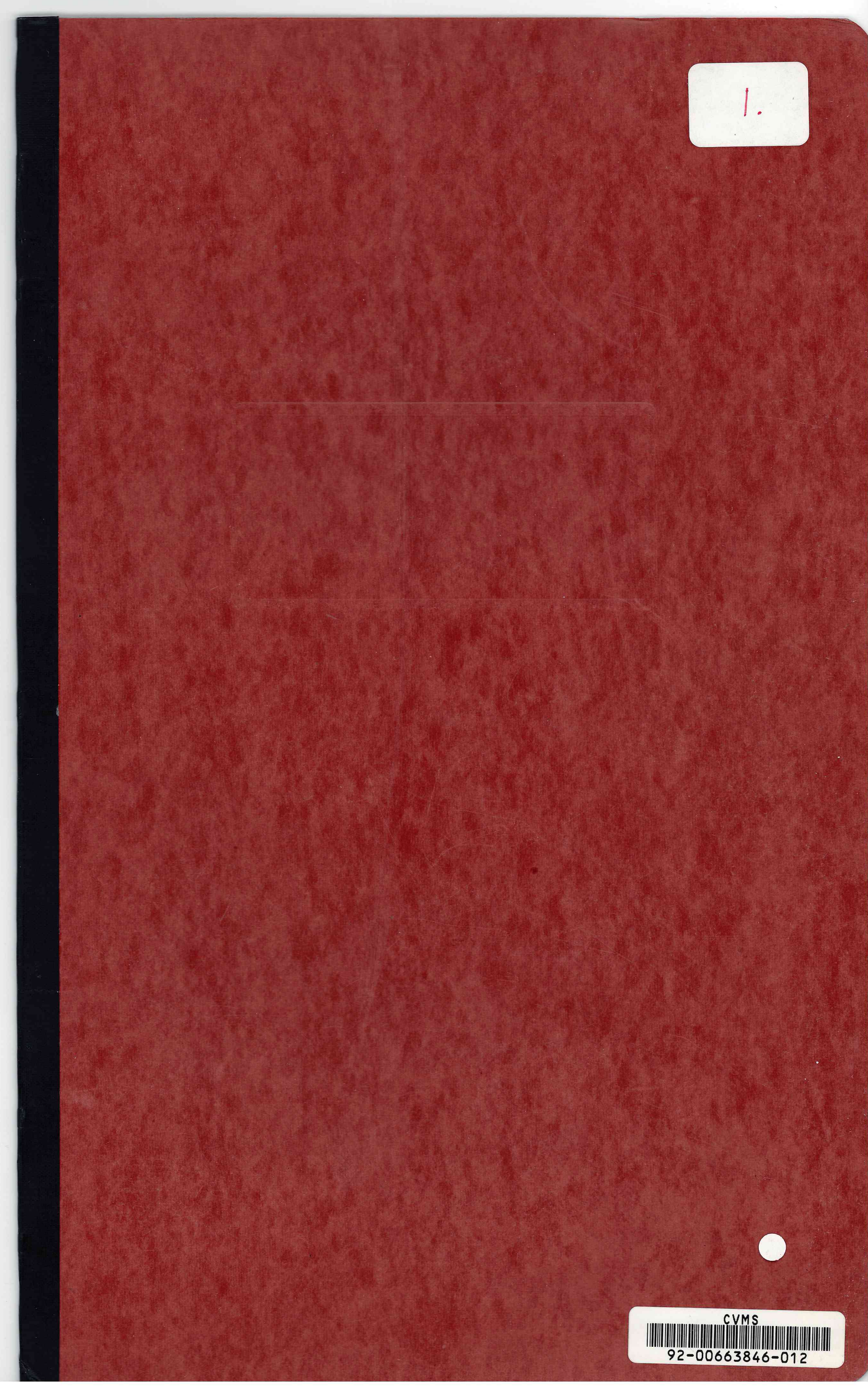




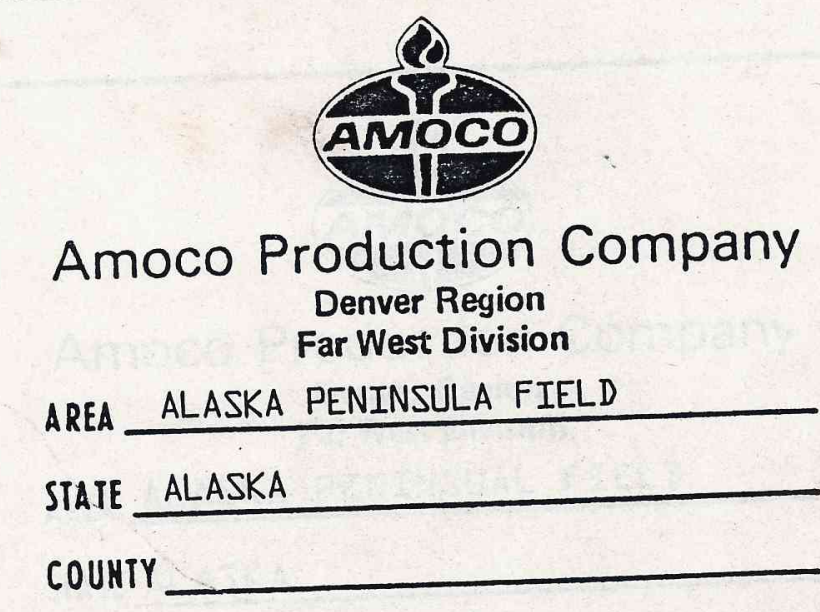

SUBJECT

1981. ALASKA PENINSULA FIELD PROGRAM REPORT

HO.

Dafe $\frac{\frac{\text { GEOLOGICAL REPORT }}{\text { DECEMBER } 198 \mathrm{I} I}}{\text { RANDALL L. BILLINGSLEY }}$

ENCLOSURES

SCALE

I PHOTOGRAPHS, FIELD NOTES, HELICOPTER LOG, SAMPLE REGISTER, BUDGET, PALYNOLOGY, WATER ANALYSIS, PRELIMINARY REPORT \{BOOK FORM\}

ᄅ 1983 I BBNC FIELD PROGRAM INDEX MAP

3 SAMPLE LOCATIONS 1993 IIELD SEASON

4 SAMPLE LOCATIONS 1 1981 FIELD SEASON

5 SAMPLE LOCATIONS 1981 FIELD SEASON

$b$ SAMPLE LOCATIONS 19811 FIELD SEASON

$?$ SAMPLE LOCATIONS 1.98 IIELD SEASON

\& GEOLOGIC MAP OF THE STANIUKOVICH MTN. AREA

9 GEOLOGIC MAP OF THE CHIGNIK ANTICLINE AREA

ID STRUCTURAL CROSS SECTIONS OF CHIGNIK ANTICLINE

11. GEOLOGIC MAP OF CHIGNIK AND SUTWICK ISLAND QUADRANGLES

- 


\section{Amoco Production Company \\ Denver, Colorado}

May 24, 1983

E. A. Williamson

CHICAGO - M/C 4701

Denver Region/Far West Division Geologic Report FW-18-81 1981 Alaska Peninsula Field Program Report

Enclosed for your information and files is a copy of the subject report by Randal L. Billingsley.

This report presents the results of the 1981 field program on the Alaska Peninsula. The major conclusions are as follows: The Ugashik conglomerate is not Miocene in age, but is probably Jurassic; the best potential reservoir in the Jurassic are the upper Kimmeridgion to lower Portlandion sands but these generally have severe destruction of porosity due to the zeolite Taumontite; Chignik Anticline is a complex thrusted structure with potential reservoir and trap potential beneath the nappe.

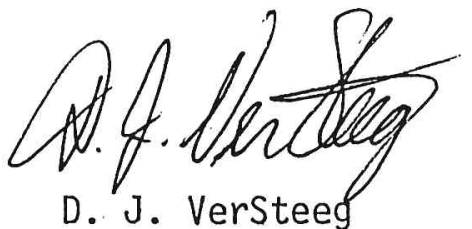

Far West Division Geologist

SM/DJV/ST

Enclosures

APPROVED FOR TRANSMITTAL:

R. C. Brooke

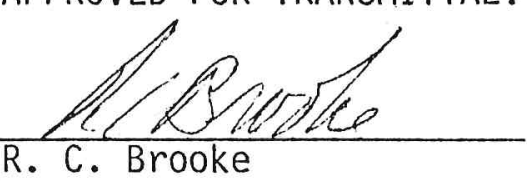


December, 1981

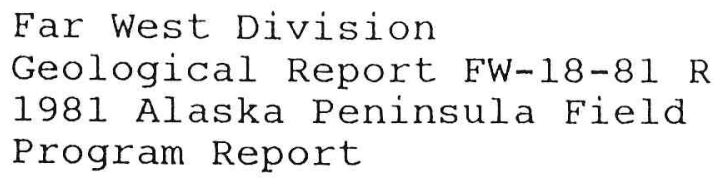

\section{INTRODUCTION}

STATISTICS

DISCUSS ION

CONCLUS IONS

REFERENCES

ENCLOSURES

Photographs

Field Notes

Helicopter Log

Sample Register

Budget

Palynology

Water Analyses

Preliminary Report from $T$. Dunn

Maps Index Map

Sample Location Maps

Geologic Map of the Staniukovich Mtn. Area, Alaska Penninsula

Geologic Map of the Chignik Anticline Area, Alaska Peninsula

Structural Cross-Sections of Chignik Anticline Area, Alaska Penninsula

Geologic Map of Chignik and Sutwik Island Quadrangles, Alaska 


\section{INTRODUCTION}

From May 30, 1981, to June 30, 1981, an Amoco field party operated on the Alaska Pennisula doing regional geologic research. The field party personnel consisted of: Randal Billingsley, Party Chief; Mitchell Cohen, Field Assistant; Ira Pasternak, Amoco Denver; Tom Dunn, Amoco Research and Robert Kemp, Amoco Denver. The field party was helicopter supported and based successively at Bear Lake Lodge (near Port Moller) Port Heiden, and the Mile High Geophysical Camp at Jensens Strip (near Becharof Lake).

The field party had six major objectives:

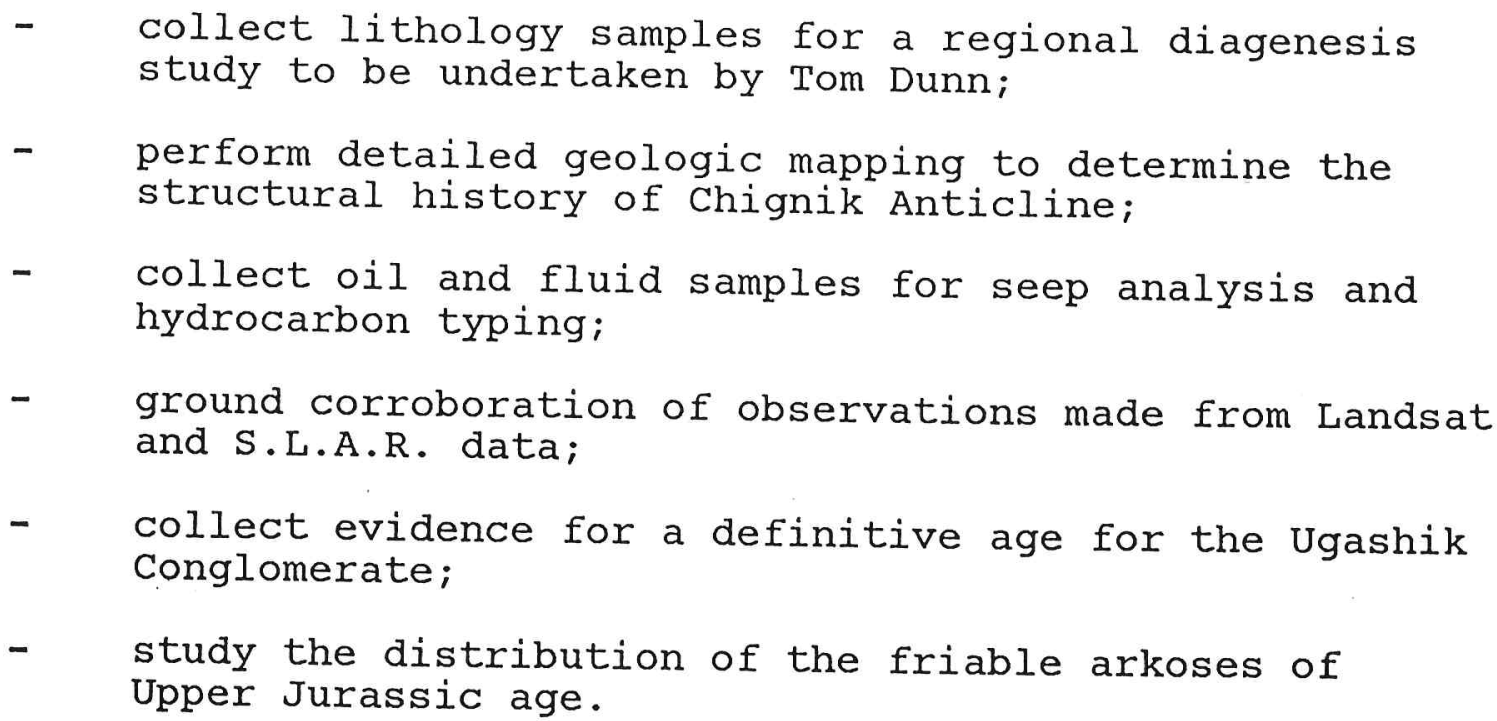

\section{STATISTICS}

During 29 working days ( 3 weather days) the field party collected 130 hand samples, 9 fluid samples, mapped approximately 300 square miles with moderate detail and field checked approximately 300 square miles of previous mapping. The total helicopter time was 95.4 hours of flight time for an average of 3.29 hours per flying day. Among the direct results were one new exploration concept and three potential leads. 


\section{DISCUSSION}

Bear Lake Lodge

The first seven days of the field program were based out of Bear Lake Lodge, near Port Moller. This location provided good access to the Port Moller-Herendeen Bay areas where outcrops of oil stained sands and various unconformities had previously been mapped. It was felt that this period would provide a good opportunity to learn the stratigraphy and collect needed data while shaking down operating methods.

One of the primary objectives of the field work had been to collect oil-stained outcrop samples to determine the state of their diagenesis. This proved frustrating in that it was very difficult to find the exact outcrop from the Amoco geologic map. We managed to find four locations with questionable oil stain or petroliferous odor. These were collected, as well as unstained samples to provide control on regional diagenesis.

Equally frustrating was the fulfillment of the second primary objective, that of sampling across the known unconformities to detect any evidence of secondary porosity due to erosion. The reconnaissance nature of the previous mapping and the poor exposure combined to defeat this objective in this area. out of frustration and as a learning exercise a geologic map was made of the area between Port Moller and Herendeen Bay (Encl. 1).

The geologic map of the area between Port Moller and Herendeen Bay exhibits a structural style that is characteristic of the entire Alaska Peninsula. The deformation in this area is not as severe as in the Chignik Anticline area but, nevertheless, similar in style and worth noting. Of particular interest is the angular relationship of the David River Fault zone and the anticlines which trend NE-SW and the faults in the NW trending valleys. This pattern of extensional and compressional features aligned parallel to each other with faulting of vertical and/or strike-slip motion occurring at $70^{\circ}-90^{\circ}$ to the anticlinal axis exists on the entire Alaska Peninsula. The significance of these relationships is unknown at this time but must be resolved before a meaningful structural model can be developed.

\section{Port Heiden}

On June 6, 1981, after one weather day and one day abbreviated by weather, the field team moved to Port Heiden, AK and occupied a barracks at the Reeve Aleution Airways terminal. The quarters 
and food were quite acceptable and the fueling facilities for the helicopter excellent. The three principal objectives of the 14 day stay at Port Heiden were:

1) To construct a detailed geologic map of the chignik Anticline from which to interpret its structural history.

2) To continue sampling for porosity and diagenesis data related to either oil or unconformities.

3) To begin to define the distribution of the Upper Jurassic friable arkoses previously described by scott McCoy.

Field mapping the the Chignik area has revealed additional evidence that points towards the interpretation of Chignik Anticline as a nappe. Previously, U.S.G.S. scientists had remarked in private conversation that they felt the anticline was either thin-skinned or intruded in its core. McCoy (Personal Comm.) has commented on the proximity of shallow and deep water Cretaceous facies across Chignik Lagoon. This summer's field work suggests a strong possibility that the entire structure is allochthonous and that the friable Upper Jurassic sands (potential reservoir?) may be intact beneath the nappe and juxtaposed against source rocks of middle and lower Jurassic age.

Burk (1965) mapped Chignik anticline as a simple anticline bounded on the northwest by normal faults and on the southeast by a high angle reverse fault. This initial picture proved far too simple. Detterman et al. (1980) depicts the Chignik anticline similarly to Burk with the addition of numerous thrust faults in the core of the feature. This summer's field work allows two more elements to be added to this complex feature; the concept of compartmentalization and the interpretation of the anticline as a nappe.

structurally, the anticline can be divided into terranes based on structural style (see Encl. 3). The northeastern terrane (the area northeast of Thompson Valley) consists of imbricate thrust faults and tight anticlines that form a deceptively simple appearing anticlinal nose. The central terrane, between Thompson Valley and Boulevard Creek, consists of monoclinal dip away from the central northeast trending high angle reverse fault. The southwestern terrane, between Boulevard Creek and Chignik Lake, consists of a central northeast trending anticlinal axis bounded on the northwest by imbricate thrusts and on the southeast by an inferred thrust fault of large scale. The area to the southwest of Chignik Lake is of apparently quite different style but was not mapped in detail due to weather and time considerations. 
Cross sections were constructed across the field area and are displayed on Encl. 4. Using Mackin's (1950) techniques of viewing geologic maps, the inferred original structure of the nappe has been restored.

Cross section $A-A^{\prime}$ depicts the structure of the northeastern terrane. The dominant features are three high angle reverse faults that are inferred to sole at depth. Near the northern end of the cross section is the Meshik River Fault which forms a prominant geomorphic scarp along the north and northwestern boundary of the field area. This fault is one of a series of basin bounding faults which form the Bristol Bay Basin. Adjacent to the Meshik River Fault is one of two normal faults that are concave towards the basin and are inferred to merge into the Meshik River Fault zone.

Cross section $B-B^{\prime}$ is across the central terrane and shows the comparatively simple structure of this area. The structure consists of opposing monclinal dip on either side of a central high angle reverse fault (Photos 1, 2). The overall impression is that the reverse fault is replacing the axis of the anticline as a result of severe shortening in a NW-SE direction. Within the core of this feature are some of the oldest exposed rocks on the Alaska Peninsula, middle Jurassic Shelikof formation. The shelikof formation contains oil stained sandstones in this area and is inferred to contain source rocks. On the northwest the terrane is bounded by the Meshik River Fault which cuts the Meshik formation of Eoceneoligocene age.

The inferred structural style of the southwest terrane is depicted in cross section C-C' oriented NW-SE (Encl. 4). The style exhibited in this cross section is derived from three lines of evidence. The monoclinal dip to the northwest in the Bristol Bay lowlands is based on seismic information. The style of the imbricate thrusting upthrown into the Meshik River Fault (Photo 3 ) is inferred to indicate the presence of a ramp at depth beneath the area of outcrop and the interpretation of the entire Nakek outcrop as a nappe is based on the fault mapped in the hills above the Chignik River. This fault, shown in photo 4 , is interpreted to represent the ancillary. faulting related to the leading edge of the nappe. A similar structural feature is shown in figure 5 of Amoco greenback F81-G-6 by S. Serra. Given that these three basic interpretations are correct it is reasonable to postulate the existence of the Upper Jurassic Staniukovich Fm. unit beneath the Chignik formation, undisturbed by the nappe. Since potential source rocks are believed present in the middle Jurassic rocks, such a structural configuration could leave the Upper Jurassic Staniukovich Fm., a potential reservoir, sandwiched between 
potential source rocks over a fairly wide area. This configuration could be an inviting exploration target. For this particular lead, the entire area between Boulevard Creek, Chignik Lake, Chignik river and the Meshik River Fault, some $70 \pm$ square miles, might be prospective.

The structural history of the Chignik area may be less complex than previously believed. Burk (1965) suggested that folding began in the Cretaceous because of variations of thickness and stratigraphic relationships he felt he could see in the Chignik/Coal Valley formation.

Field mapping during this project did not reveal significant evidence of deformation prior to the U. Cretaceous. The uppermost Jurassic map unit (JRNU), a conspicuous dark green siltstone unit with Buchia, was present over the entire map area where it hadn't been removed by faulting. It seemed to be of approximately constant thickness (although sections weren't measured) and any variations in thickness of the overlying Coal Valley formation seemed explainable by facies changes as well as pre-existing structure. Therefore, the age of chignik anticline is postulated as upper Eocene to Oligocene on the basis of the Meshik formation being the youngest formation folded into the structure. A minimum age can be established as Miocene on the basis of two intrusives which intrude thrust sheets near Fan Creek mapped as Miocene-Pliocene by Detterman et al. (1980).

Within the upper part of the Naknek formation in the Chignik area lies a series of tan, friable arkoses strikingly dissimilar to the bulk of the Naknek formation. These sandstones have been previously described by other workers (MCCoy, personal comm.) and were mapped by Burk (1965) as part of the staniukovich formation. Additional investigation into the lateral extent of these sands was one objective of the field party.

The arkoses were measured to be some 1,400 feet thick in the vicinity of Blue Violet Creek (Phillips Petroleum Co. section). The unit is relatively soft compared to the other units present and tends to form saddles due to differential erosion (Photo 5). The soft character of the unit also tends to restrict the number of good exposures. Frequently the unit appears well exposed from a distance but on arrival all that is observed is rubble.

Whereas most of the Naknek formation is composed of hard, tight green sands and silts the friability of the arkoses is seen as evidence of their potential as a reservoir. Tom Dunn of Tulsa Research is presently investigating the character and history of cementation of this unit. Until proven otherwise, however, it will be considered a potential reservoir. 
Within the immediate area of Chignik anticline the friable arkoses are overlain by a dark green siltsone unit (JRNU) containing Buchia piochi and Buchia mosquensis. The presence of these fossils suggest an upper Kimmeridgian to lower Portlandian age for the siltstone unit and thus a somewhat older age for the friable arkoses. This is born out by mega plant and palynology data which will be discussed later. The friable arkoses are probably no older than middle Kimmeridgian because they appear to overlie conglomerates in the UgashikWide Bay areas that are believed to represent a eustatic fluctuation of sea level at middle Kimmeridgian.

Burk (1965) cites a series of collections (his own and others) giving the staniukovich formation an age span from the upper middle Kimmeridgian into the Valanginian (lower Cretaceous). From this it is reasonable to include the upper Jurassic friable arkoses encountered during the field work in the classic staniukovich formation.

Within the area covered during the stay at Port Heiden the upper Jurassic friable sands crop out extensively. The sands are exposed in the mountains to the southwest of Chignik Lake, along the northwestern margin of Chignik Anticline itself and in the hills above Chignik Lagoon (Photo 6). The exposures in the hills above Chignik Lagoon had not previously been recognized prior to this summer. Burk (1965) cited U.S.G.S. work reporting Chignik formation resting unconformably on oxfordian to E. Kimmeridgian Naknek formation on Chignik Bay. Yet, the upper Jurassic friable sands are present in the hilis between Thompson Valley and Alfred Creek. The presence or absence of these sands has frequently been used in the past as evidence for previous structural activity in the cretaceous. The evidence from this summer's work would suggest that the absence of these sands is probably due to structural complications rather than an angular unconformity. This would imply no folding prior to deposition of the chignik formation.

Along the northwest limb of Chignik Anticline the upper Jurassic friable sands are apparently faulted down by the Meshik River Fault. Such a structural configuration undoubtedly juxtaposes the friable arkoses against the relatively impermeable lower Naknek or shelikof formations at depth. It is therefore conceivable that a play could be made for downthrown fault closure with the upper Jurassic friable sands as reservoir. The Pan Am Hoodoo Lake did penetrate the equivalent sand package downthrown to the David River Fault near Port Moller, confirming its presence, although tite, downthrown to an analogous structural feature. 
Lead areas with potential for this type of play would be located on the northwest limb of Chignik Anticline, particularly in the vicinity of Black Lake, and to the west and south of the Ugashik Lakes between Lower Ugashik Lake and Cinder River, downthrown to the Bristol Bay Fault.

Jensen's Strip 6-20-6-30, 1981

On 6-20 the field party moved to Jensen's strip where the Mile-Hi seismic crew had established a camp.

This final leg of the field season had four main objectives:

- calibration of remote sensing data

- re-examining the Ugashik Conglomerate for evidence of its age

- re-collect the possible seep reported the previous summer

- collect more samples of oil stained sandstones

The underlying hypothesis behind the use of remote sensing information on the Bristol Bay lowlands resulted from a chance photograph taken by Chuck webb in 1980. This chance photograph of an apparent fault scarp together with observations from Landsat photographs led to the acquisition of side looking airborne radar (SLAR). Analysis of the SLAR data revealed abundant evidence of Quaternary faulting in the Bristol Bay lowlands. It was hoped that ground confirmation of features observable on the radar would enhance the reliability of seismic mapping by constraining possible fault interpretations.

In ten days of over flying the tundra relatively little direct evidence of quaternary faulting was observed. The location of Webb's original scarp was discovered and rephotographed near the mouth of the King salmon river, south of pilot point (Photo 7). Also found and confirmed was a prominant drainage anomaly northwest of Upper Ugashik Lake which has since been related to a fault zone seismically (Photo 8 ). The main conclusion from this effort is that the value to be derived from remote sensing data will be derived in the office and field checking will confirm only the most striking features and not the subtle vegetation and drainage anomolies most often observed with the synoptic view of remote sensing data. 
The Ugashik Conglomerate (Conti, 1974) formed the basis for the Ugashik marine sand fairway play which was one of the concepts that led to the acquisition of the BBNC concession. The Ugashik Conglomerate itself is a massive cobble to boulder conglomerate that crops out extensively along the southeastern shore of the Ugashik lakes that was originally placed in the Naknek formation by Burk (1965). Palynolgy samples from the conglomerates have repeatedly proven to be barren or effectively so. Amoco scientists have repeatedly sought to place the Ugashik Conglomerate within the Tertiary (Conti, 1971; Conti and Self, 1974; Connelly, 1977, 1978). In order to resolve this controversy another examination of this unit was undertaken.

A three sided approach has been undertaken to resolve this question. Palynology, structural geology, and physical stratigraphy. During the field work this summer ten additional palynology or mega plant samples were taken in optimum places with only moderate success (Appendix 1). In addition $R$. $W$. Baxendale re-examined 38 samples from previous field seasons (1968-1978). The area was examined closely for evidence of the major faulting necessary to segregate the Ugashik Conglomerate from known upper Jurassic conglomerates in the area. In the office measured sections by previous workers were compared with sections of other rocks in the area to check for physical similarities.

It is the opinion of this writer that the Ugashik Conglomerate is a facies of the Naknek formation and not of Tertiary age as proposed by others. This opinion was derived from the following lines of evidence:

1) After combining the re-interpreted palynology with all known structural information, no conclusive evidence would be found to justify an age call younger than Eocene.

2) It was this writer's opinion that the Upper Jurassic friable sands, which are exposed at Mt. Peulik, were stratigraphically higher than the Ugashik Conglomerate, thus pointing to a Upper Jurassic age for the conglomerates.

3) No evidence was found for major faulting in the valley between the Ugashik hills and Wide Bay Anticline.

4) The Ugashik Conglomerate seems to correlate well (allowing for facies changes) to other Jurassic Naknek formation measured sections in the area. 
The reversion of the Ugashik Conglomerate to Jurassic age poses no serious problems for our exploration effort.

It does, however, support the concept of a major structural break between wide Bay and the Dog Salmon river, since Tertiary or Cretaceous rocks are very scarce north of the Dog Salmon river, upthrown to the Bristol Bay-Bruin Bay Fault System.

One important implication of this fact is that the Upper Jurassic friable sands are observed to extend as far north as Mt. Peulik (Photo 9) and thus virtually to the edge of the Bristol Bay Fault. As previously mentioned, one possible play concept is to look for these sands downthrown on the Bristol Bay fault and the gravity data in-house does reveal the possibility of such a trap on the acreage near the Dog Salmon River.

During the summer of 1980, D. Stemmler noticed on oily white film on water surfaces near a seismic line being shot. He sampled the film and Tulsa Research concluded that crude oil was present. The third objective of this leg of the field work was to duplicate these results.

Using Stemmler's verbal description of the phenomenon and its location, nine water samples were taken in an effort to duplicate the previous results. Photo 10 is a picture of the phenomenon closest to his verbal description. Test results from Tulsa reveal no significant hydrocarbons present in any of this summer's water samples. Since the white scum was present on virtually all the standing water in the area, the evidence would seem to point towards the first sample having been contaminated.

The effort to collect more diagenesis samples was not successful for two reasons. It was not possible to find the sites near Pearl Creek Dome and Paule Bay and the sites at oil Creek were within a newly constituted wilderness area and not accessable via helicopter.

On the evening of June 30, 1981, following a day of excessive winds and an accident, the helicopter was released and the field assistants sent to Anchorage for emergency treatment of one sprained ankle. At the time it was thought that the nearest $x$-ray facility for public use was in Anchorage; however, it was later learned x-ray facilities are now available in King Salmon. 


\section{CONCLUSIONS}

The following conclusions are preliminary and may need to be modified as information from laboratory analyses become available.

It is unlikely that porosity will develop beneath unconformities on the Alaska Peninsula. T. Dunn is investigating this possibility but prospects are not good at this time. (See Tech. Service Rpt. 819293SX for details)

- Considerable laumontite cement exists but its genesis is not well understood.

- Chignik Anticline is the result of a major compressional event sometime between lower oligocene and middle to upper Miocene.

- The compressional event was followed by an extensional event also in the Miocene which formed the upper reaches of the Bristol Bay basin.

- The seep previously reported near Egegik is probably not caused by thermally generated hydrocarbons.

- Many features observed on the remote sensing data are observable on the ground and have structural significance.

- The Ugashik conglomerate is at least as old as Eocene and is probably part of the U. Jurassic Naknek Fm. as previously mapped by Burk (1965). It is not Miocene or younger and cannot be used to justify a "marine sand fairway play."

- A belt of upper Kimmeridgion to lower Portlandian in friable arkoses extends from the southwestern part of the Chignik area northeast at least as far as Mt. Peulik. These sands are the best, if not only, chance for a reservoir now known in the Jurassic. Three leads utilizing these sands as a potential reservoir were delineated as a result of this summer's field work. They are: the southwestern part of Chignik Anticline, the Black Lake area and southwest of the Ugashik Lakes. 


\section{REFERENCES}

Burk, C. A., Geology of the Alaska Peninsula - Island ArC and Continental Margin, GSA Memoir 99, 1965.

Connelly, W., 1979, Data Compilation and Preliminary summary, 1977 Alaska Peninsula Field Project, Amoco Rept. FR-02-79.

Connelly, W., 1979, Data Compilation and Summary, 1978 Bristol Bay Field Project, Amoco Rept. FR-03-79.

Conti, L. J., Geology of the Ugashik Lakes Area, Amoco Geological Memo No. 154, September 1971.

Conti, L. J., and G. W. Self, 1974 Geological Maps of the Alaska Peninsula, Lower Cook Inlet and Northern Bristol Bay, Denver Division Rpt. 137.

Detterman, R. L., et al, Generalized Geologic Map of Chignik and Sutwik Island Quadrangles, Alaska, USGS Misc. Field studies Map, MF-1053 A, 1979.

Makin, J. Hoover, 1959, the Down-Structure Method of viewing Geologic Maps, Jour. Geology, Vol. 58, 58-72. 
Photb 1. View northeast along the core of the central terrane showing monoclinal dip away from the central high angle reverse fault.

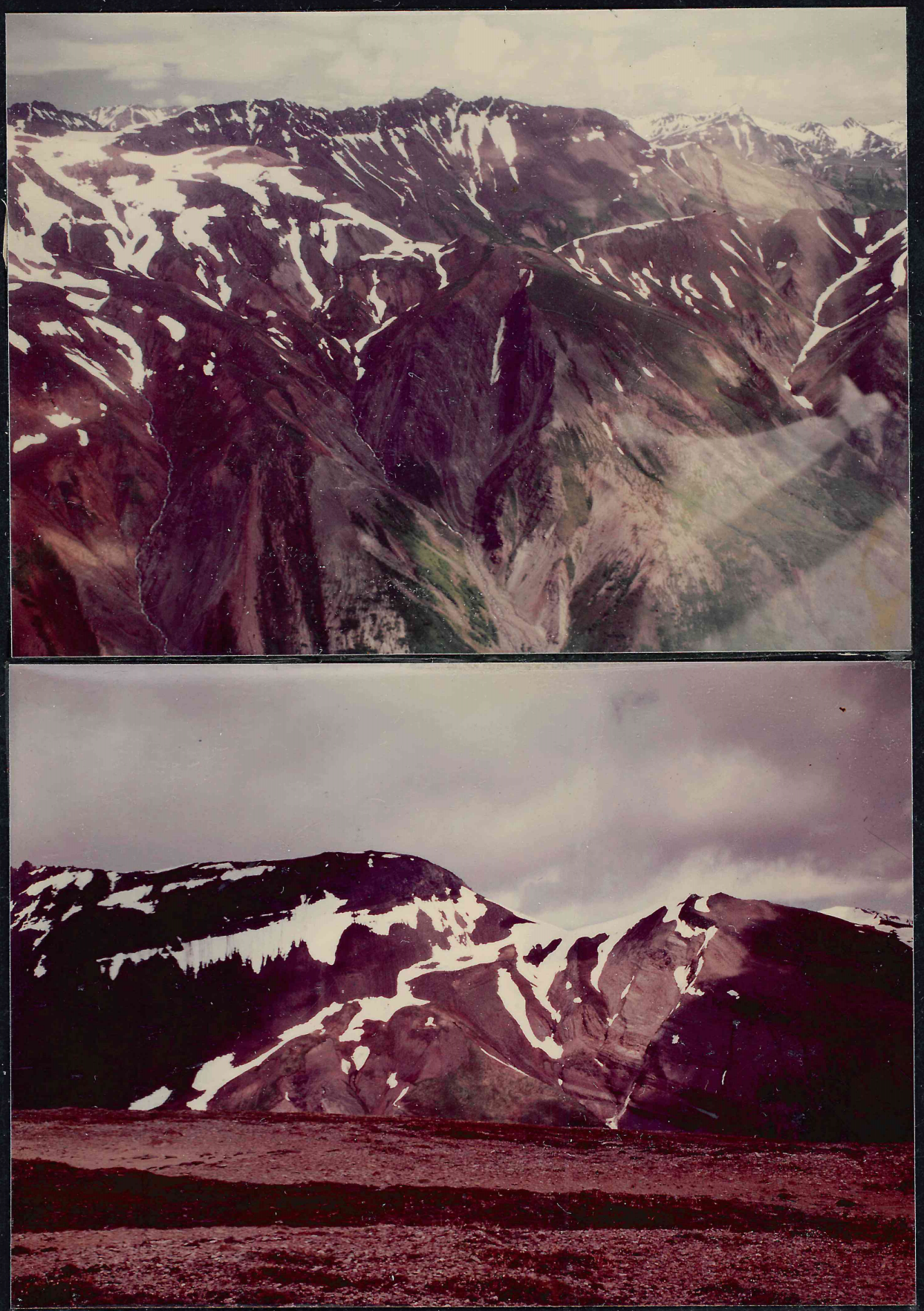

Photo 2. View northeast across Nekita Creek showing the style of high angle faulting of the central terrane. 


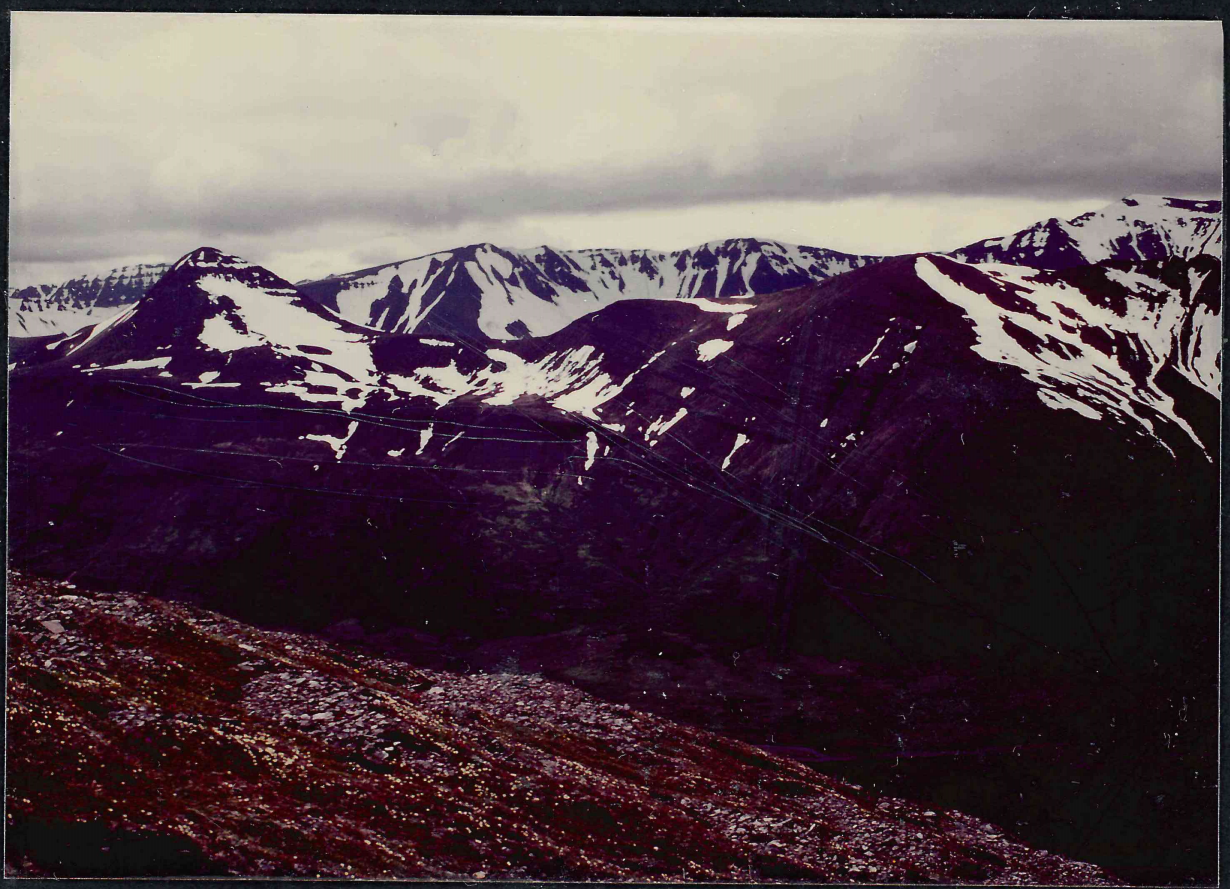

Photo 3. View southwest across Boulevard Creek showing a ramp in the imbricate thrust zone along the northwestern margin of the nappe. 


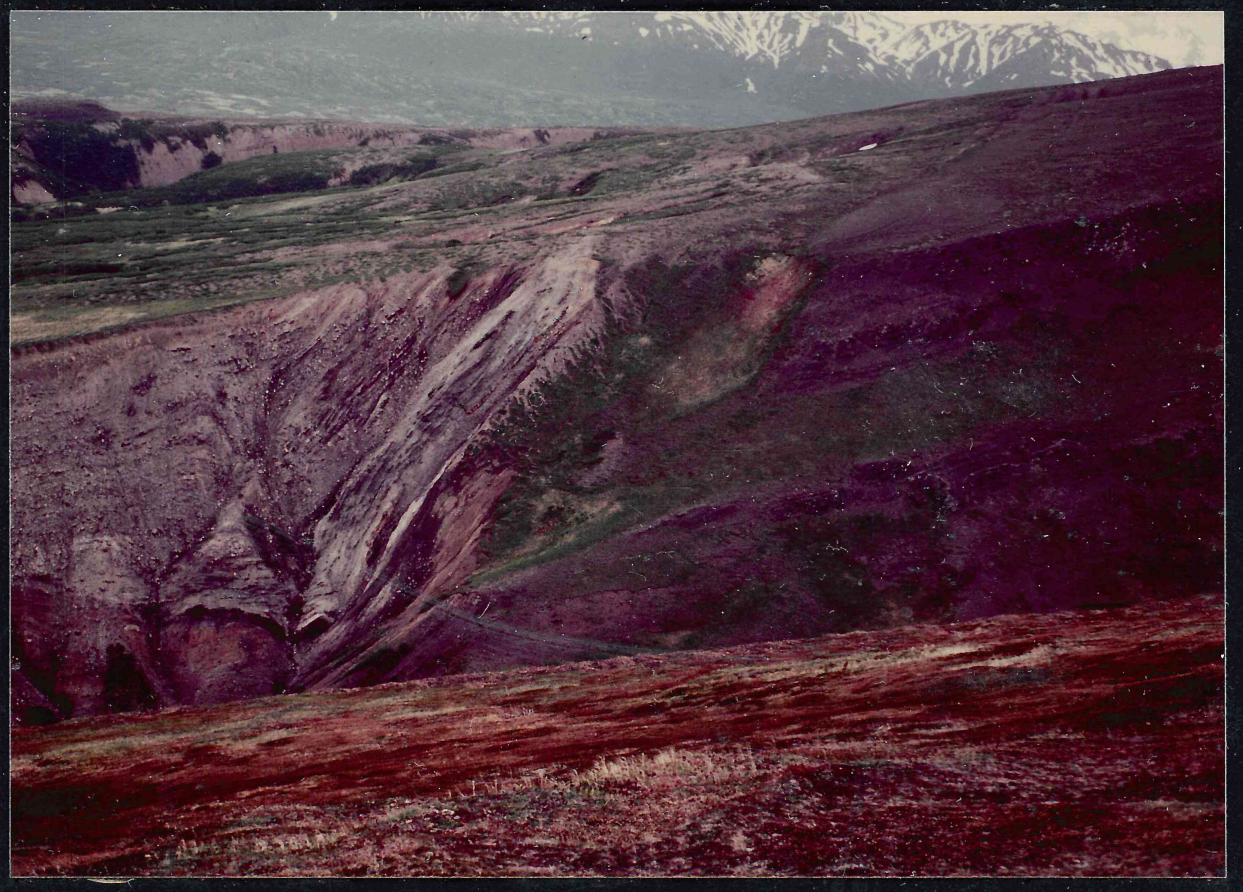

Photo 4. This fault is interpreted to be a reverse fault related to the leading edge of the nappe as shown in the diagram below.

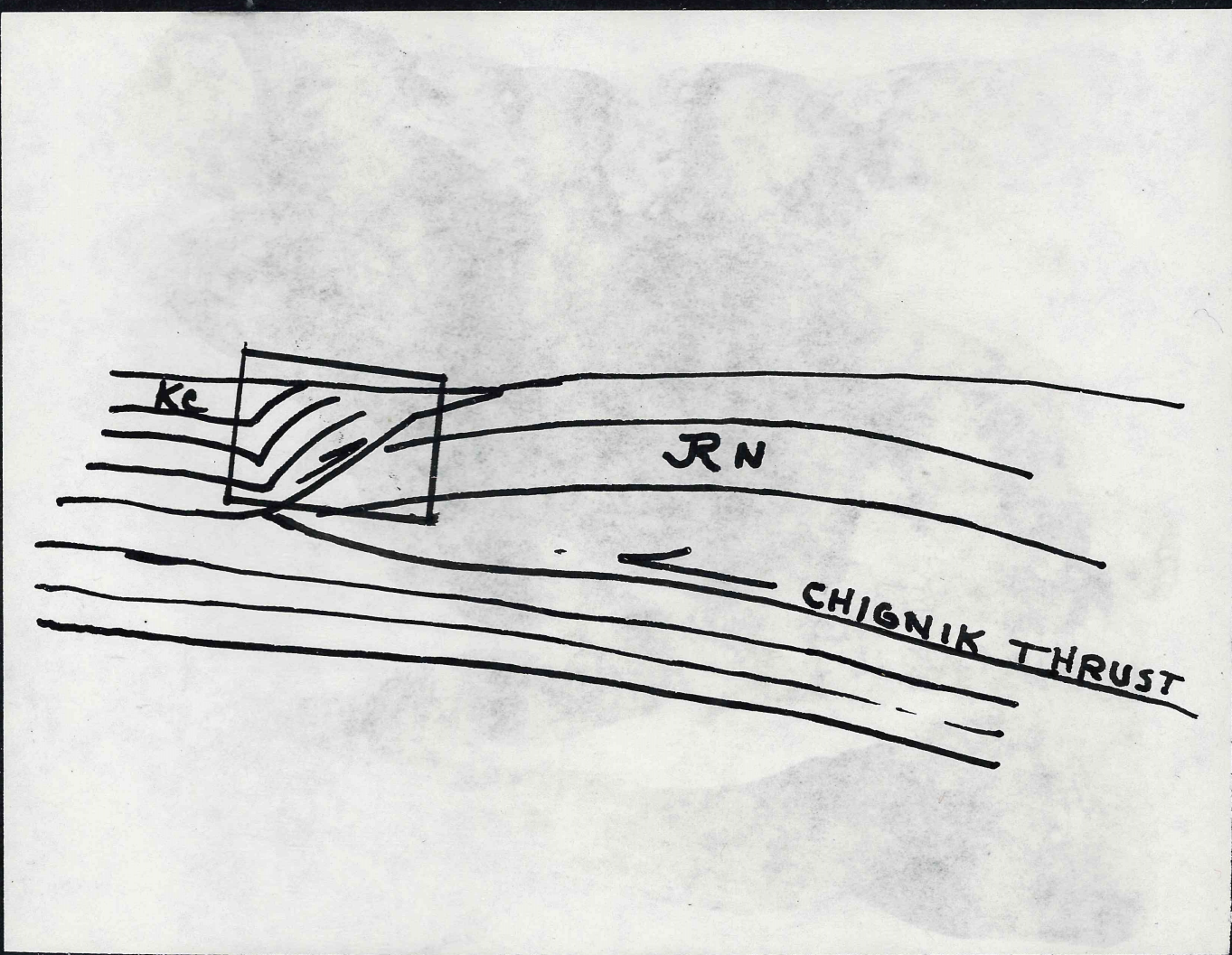




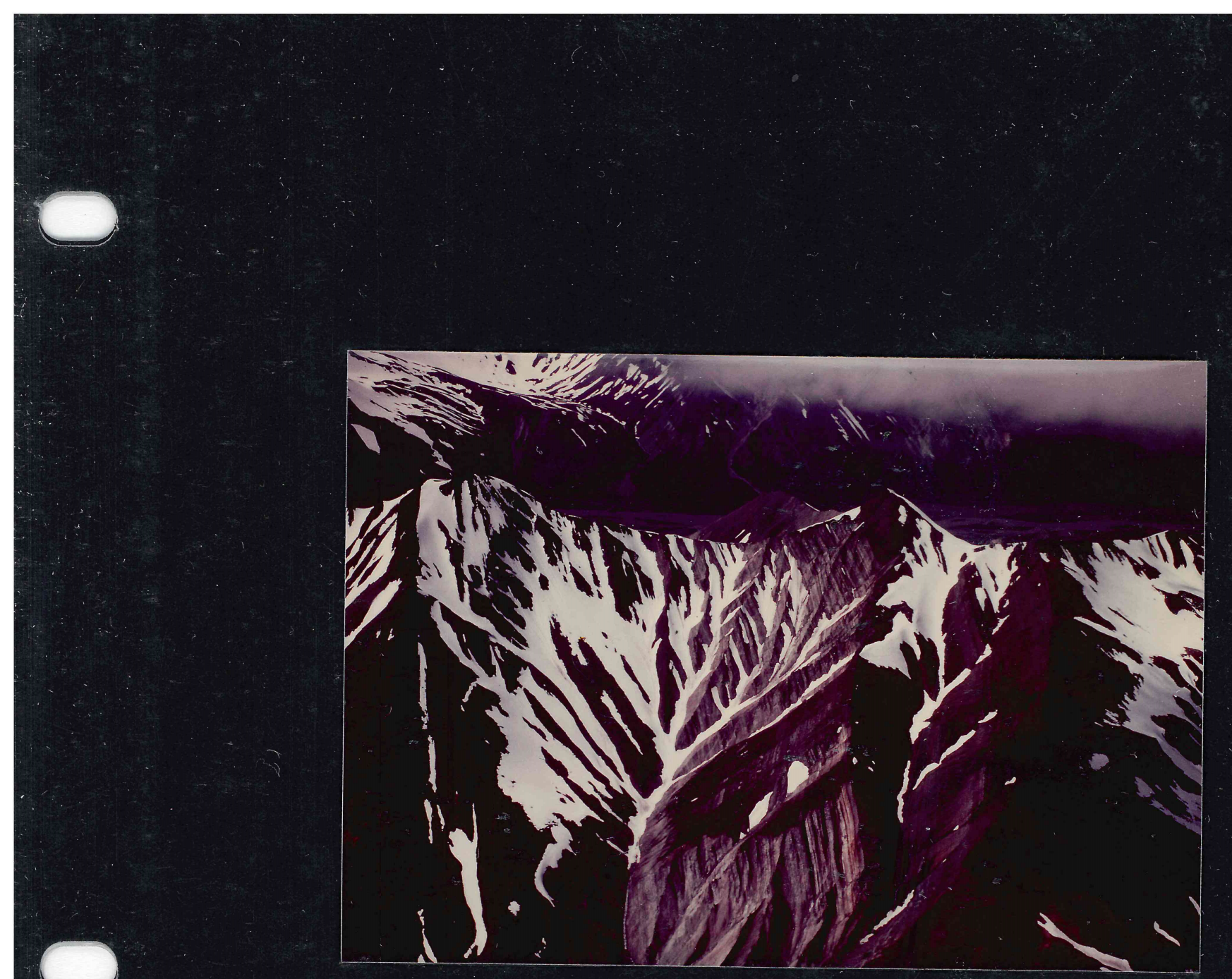

Photo 5. Aerial view of northwesterly dipping Mesozoic beds southwest of Blue Violet Creek. The light colored Upper Jurassic friable arkoses form the saddle between the two higher points on the ridge. 


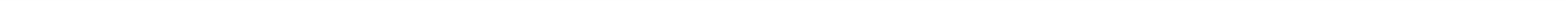




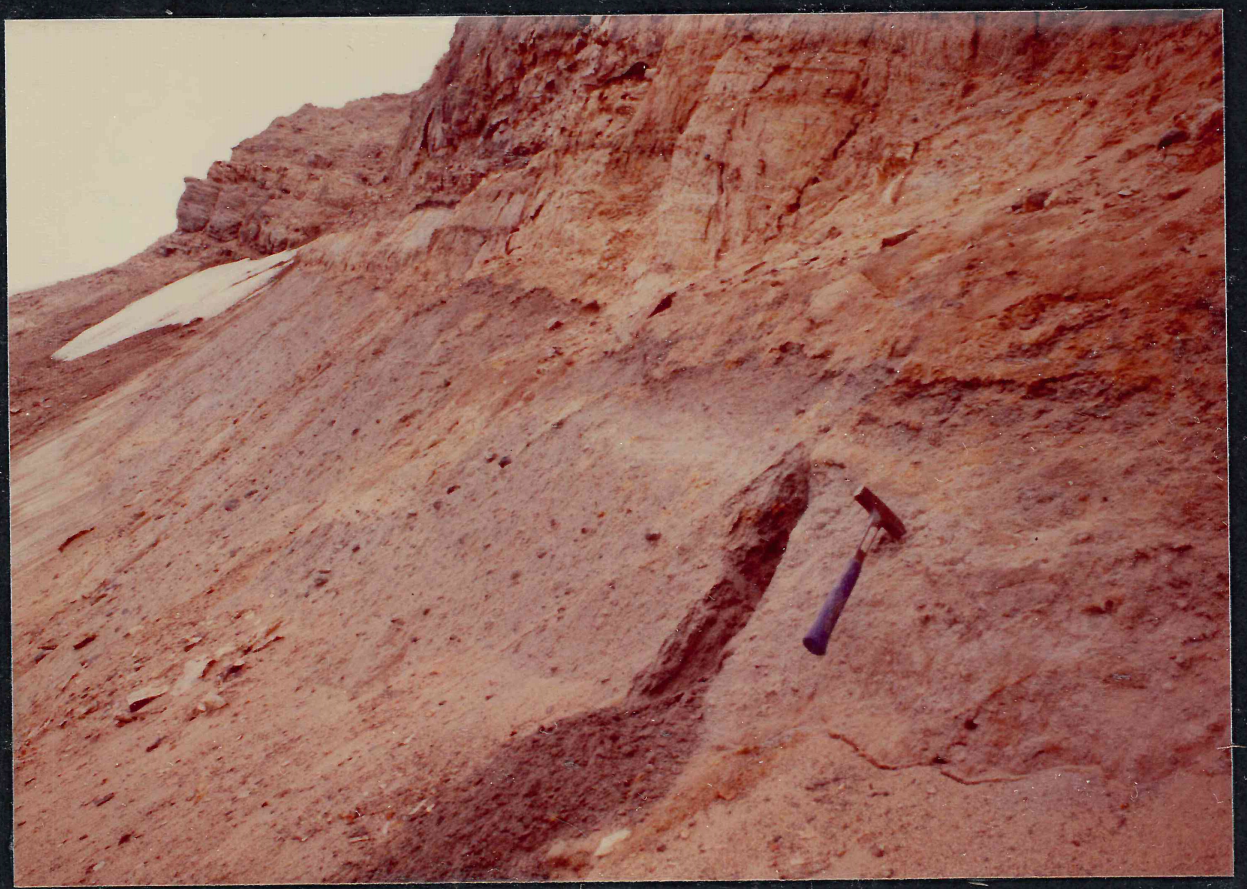

Photo 9. Outcrop of Upper Jurassic friable arkoses in south gates of Mt. Peulik. Identifiable mega plant fossils were recovered indicating Upper Jurrassic age. 


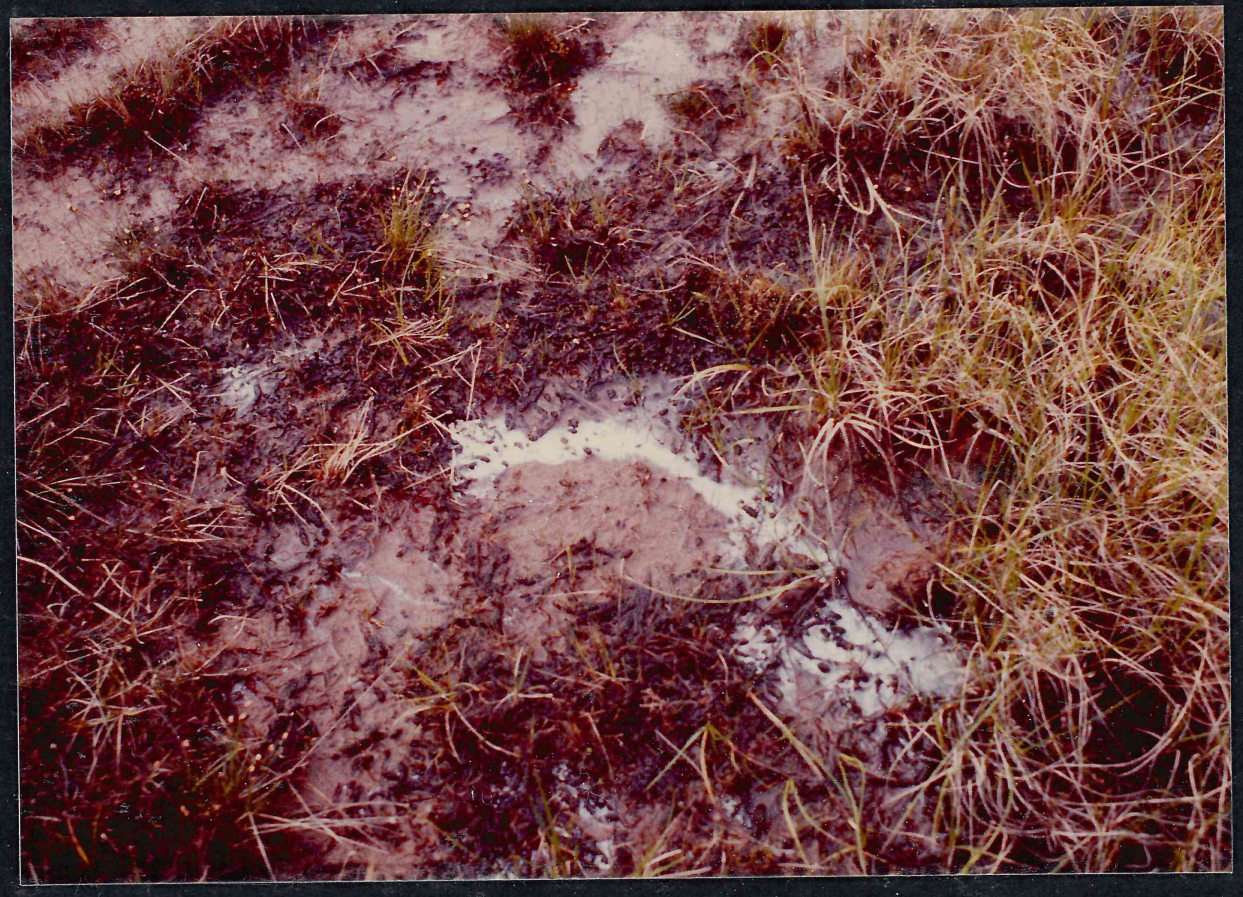

Photo 10. Milky white film previously described and sampled by Stemmler in 1980. Test results suggested the film was biodegraded oil, yet tests from this summer were negative. The ubiquitous nature of this phenomenon leads this writer to down grade the probability of the film being the result of thermally generated hydrocarbons. 


\section{FIELD NOTES}

\section{Day 1 Summary}

Left Anchorage and flew to Bear Lake Lodge. Settled in, lunched, and did short recon hop. Stops at Cape Seniaven, Three Hills and tried to find the oil seep north of Cape Seniaven.

Cape Seniaven appeared to be eroded Pliocene beds rather than QV as mapped. Sharply tilted, faulted.

\section{Day $2 \quad$ stop 21}

Bear Lake Lodge, partly cloudy, patches of fog.

On outcrop mapped as Herendeen Unit forms notches facing Port Moller on Mt. Staniukovich.

Some Is. float w/Inoceramus frags. Petroliferous (fetid) sandstone grey salt \& pepper appearance, very fine-grained w/occasional Inoceramus prisms.

Low angle trough cross-beds. Marine foreshore sand, laterally extensive.

Bioclastic sand with some quartz grains. Coarse and fine layers, S\&P(?) N50E $38^{\circ} \mathrm{NW} 38^{\circ}$

$$
\begin{aligned}
& 81-\mathrm{RB}-0001 \text { Lith } \\
& 81-\mathrm{RB} \quad 0001 \varnothing
\end{aligned}
$$

on ridge, contorted bedding

trough $\mathrm{x}$-beds

Stop 22 Left 8:00 a.m., RTN 3:30

Coal Valley

Intending to sample Js thru Kev(?)

$81 \mathrm{RB} 0002$ Lith Js near waterfall

Vfg salt \& pepper as before on Stan Mtn (Stop 1) weathers dk. gray and looks like ls.

$81 \mathrm{RB} 0003 \mathrm{Js}(?)$ lith from higher in sect seems harder (more cement?). Strong fetid petroliferous odor. Unable to find Herendeen or Kcv. Ate lunch. 
Stop 23 Guli Pt.

Looked unsuccessfully for inactive seep as mapped on Amoco map. Took Lith samples 81 RB 0004 A\&B

Stop 24 Heren on Herendeen Bay

Stopped to look at intensely deformed Tmb. on shore of Bay MITCHELL TAKES PICTURE OF FAULT

This is probably a spur off the David R. Fault system. Everything is quite messed up.

Day 3 Left $8: 30$ p.m.

Looking for oil seep.

Stop 1 at Tolstoi unit on westside Port Moller. Case of mistaken ID. Took sample anyway 81RB 0004 L(ITH) A\&B $81 \mathrm{RB} 0005 \mathrm{C} \mathrm{L}(\mathrm{ITH})$ Zeolite? Calcite

For comparison $\mathrm{w} /$ regional sediments

Stop 2 Saw 4 bears, 1 wolverine and 2 eagles.

Found the stepovak ss on the cliff face and sampled for lith and diagensis B1-RB-0006

$\mathrm{B} 1-\mathrm{RB} 0006 \mathrm{~A}$

Hopefully this is oil stained.

The Ss was quite friable and dark chocolate brown.

Moved eastward on coast and went thru $\mathrm{Cg}$ unit (Tolstoi?) and then into lignitic $K$ marine (Ss?) (Kcv?)

Upward of 15' of lignitic material interbedded $\mathrm{w} / \mathrm{Ss}$ units w/Inoc./frg. and other marine fossils.

Sampled lignitic material.

81 RB 0007

Day 3 stop 3

Kc on top of ridge mapped as inactive seep. Found dark colored salt \& pepper ss, quite rotten, dark grey to black also Ss present which did not seem stained. Ira does not entirely believe the stains are hydrocarbons. 
Took Samples:

81 RB 0008A $\quad$ Stained
81 RB $0008 B \quad$ Unstained
81 RB 0008 P Paly (shale)
81 RB 0008 CL Lith, very hard, tight graywacke additional
diagenetic control

Ira thinks these sands are crevasse splays.

Day 3 Stop 4 Coal Bluff

Mapped previously as $\mathrm{KcV}$ massive $\mathrm{Cg}$ of well-rounded clasts

Day 4

- Penisular Airways 5322485 Cold Bay

246 - 3372 King Salmon

- 3373 King Salmon

Stop 1 RS Stop 41

Olive gray, fine to medium grain Ss w/stringers of well rounded pebbles (black chert) highly fractured, low angle $\mathrm{x}$-beds (trough?) pebbles occur as lags. Pelecypod fossils (Buchia?)

Stop 2 JKS

Olive gray fine ss weathers - gray to tan faint $\mathrm{x}$ beds heart of anticline. No fossils 81 RB 0009L Lith Sample

stop 3

Shale w/Carbonaceous debris. Pebble lags observed in float. Ira thinks the environment is shallow nonmarine to marine.

Stop 4

Olive gray ss high angle $\mathrm{x}$ beds 3-4" beds.

3-4" beds

STR N47E

Dip $20^{\circ} \mathrm{SE}$

Stop 5 as abv

STR N $4^{\circ} \mathrm{W}$

Dip $37 \mathrm{NE}$ 


\section{Stop 6}

Small hill previously mapped as Tos is in reality some sort of volcanic. Took sample for age date.

81 RB 0010

Stop 7

Cliff of JKs abv. Linden Creek STR N22 $\mathrm{W}$

Dip E $24^{\circ} \mathrm{NE}$

Believe fault runs in the creek bed because exposure of $\mathrm{KCV}$ on coast is structurally lower.

RB 810011 MP

\section{$\underline{\text { Day } 5}$}

Late start because of low ceiling

Stop 1

STR N82W Dip $22^{\circ} \mathrm{N}$

Sample 81 RB 0012 L(ith)

Jn exposure on coast. Stopped to gain feel for Naknek.

Very well indurated olive gray ss with fine grained intervals soft sediment deformation, rip-ups and lag

deposit. Look similar to JKs except no x-beds, no fossils and seems harder. Ira says it is no harder than JKs we saw in Coal Valley. He could be right. Ira sees carbonaceous materials here also. Outcrop has mottled appearance, dark and light splotches. Dark is maybe oil? Took samples of dark RB 810012 BL

Ira took picture of me in front of shattered $\mathrm{Jn} \mathrm{w} / \mathrm{b}$ ands of Lt and dark fine grained material.

Stop 2

Slope abv Portage Valley

KC w/ leaf impressions, coarser sandstone. RB 810013 Lith RB 810013 MP Mega Paly

RB 810013 P Paly 
Stop 3

Herendeen Bay RB 810014 L

This hill is mapped as KcV. It does not, however, look like KcV. It is a very massive unit with isolated boulders, pieces of rounded coal floating in a matrix of $\mathrm{fg}$. dk. olive gray ss and sh. There is some burrowing and evidence of pelecypods although none is seen in place. There are some round concretions.

The crop is highly fractured. It would be nice if it were Hoodoo.

Stop 4

Herendeen. Petroliferous, calcareous, no Inoceramus observed.

RB $810015 \mathrm{~L}$

Day 6

Bad weather, no flying, fog, low ceiling, rain. Morning spent on housekeeping, packing samples, drafting, planning.

Box 1 List of Samples

\begin{tabular}{|c|c|c|c|}
\hline $81 \mathrm{MC}$ & 0001 & & \\
\hline 81 & 0001 & $\varnothing$ & \\
\hline 81 & 0002 & L & \\
\hline 81 & 0003 & L & \\
\hline 81 & 0004 & & \\
\hline $1 \quad \mathrm{RB}$ & 0005 & L & $A B$ \\
\hline & 0006 & A & \\
\hline & 0007 & & \\
\hline & 0008 & AL & \\
\hline & 0008 & CL & \\
\hline & 0009 & L & \\
\hline & 0010 & & \\
\hline & 0011 & MP & Bag A \\
\hline & 0012 & L & \\
\hline & 0013 & MP & \\
\hline & 0013 & $L$ & \\
\hline & 0013 & $\mathrm{P}$ & \\
\hline
\end{tabular}


Box 2

$\begin{array}{lllll}\text { RB } & 81 & 0012 & \text { BL } & \\ \text { RB } & 81 & 0006 & & \\ \text { RB } & 81 & 0008 & \text { BL } & \\ \text { RB } & 81 & 0011 & \text { L } & \text { ABCD } \\ & & 0011 & \text { P } & \\ \text { RB } & 81 & 0008 & \text { P } & \\ \text { RB } & 81 & 0013 & \text { P } \\ \text { RB } & 81 & 0014 & \text { L } \\ \text { RB } & 81 & 0015 & \text { L } \\ \text { RB } & 81 & 0015 & \text { LA } & \end{array}$

Day $7 \quad 12: 00$ P.M. , 6/5/81

Late start, bad weather, working up face of hill - behind lodge where T.S. section of Tmb \& Tos lies.

Stop 1

Ira has found petrified wood in Tos. We've identified basal $\mathrm{cg}$. of Tmb and are looking for fossils. Taking samples of Tos for Paly.

$$
81 \mathrm{RB} \quad 0016 \quad \mathrm{P} \& \mathrm{MP}
$$

After climbing up several hundred feet we came to the true basal cg with the fossils. I think we traveled the wrong nose and as a result saw a great deal of stepovak.

We collected the $\mathrm{cg}$.

$81 \mathrm{RB} 0018 \mathrm{M}$ Paleo

$81 \mathrm{RB} 0017$ is a Paly sample 15' below the contact.

81 RB 0019 Paly sample near base of exposed Stepovak section.

Day $8 \quad 6 / 6 / 81$

Travel to Port Heiden 


\section{Day 9 stop 91}

$$
\text { Sample } 81 \text { RB } 0020 \text { L }
$$

Outcrop of Js (as mapped by Wilde)

Highly fractured, very fine grained ss. No bedding evident due to fracturing. Very tight-silica cement. No fossils evident. Weathers grayish tan.

The rocks exhibit a rodding type of structure.

AZ $146^{\circ} \mathrm{Plg} .36^{\circ}$ Took Az. \& Plg. Similar to quartz rods.

Mitch takes picture

Roll \#4 First Exp.

Stop 92

Opposite wall of valley is composed of alternating black sandstones, and slst's capped by a massive gray ss $\sim 75^{\prime}$ thick. Took sample of black shale with forams (?) for dating. 81 RB 0021 micro paleo.

Stop 93

Lunch Jks $\quad 81 \mathrm{RB} 0022 \mathrm{~L} \quad(\mathrm{cg})$

$81 \mathrm{RB} 0022$ LA (Cg)

Outcrop of Jks. Coarse grained tan ss mapped as Jn by wilde. Thin cg. (4) units.

Stop 94

Jn mapped as Jn by Wilde. Med-f grained gray ss, few outcrops.

STR $139^{\circ}$

Dip $22^{\circ}$

x-beds 12" amplitudes w/Buchia, occasional laminated beds, some shale inter beds. $81 \mathrm{RB} 0023 \mathrm{~L}$

81 RB 0023 MP Pelecypods

Stop 96

Kc or KcV intruded (?) by sills (?)

81 RB 0025 L

$81 \mathrm{RB} \quad 0025 \mathrm{~A}$

$81 \mathrm{RB} 0025 \mathrm{~B}$ 


\section{Stop 97}

Stopped to check out some tt. gray appearing rocks, fossil ferns, cycads (?).

81 RB 0026 MP

Day $10 \quad 6 / 8 / 81$

PDN Cape Nickolai

Stop 101

Observed Hoodoo Fm overlain unconformably by Tolstoi in cliffs. Hoodoo $\mathrm{Fm}$ is definitely deep water turbidite facies. Observed were sandstone load casts, flute structures, etc.

Took mucho pictures of the unconformity

Stop 102

Stopped on crest of Castle Cape to see Tolstoi Fm. Forms hogback along axis of island. Lenticular beds of pebble and cobble cg. Cg mixed in $\mathrm{w} / \mathrm{ss} \& \mathrm{sh}$.

Little lateral continuity

Probably non-marine

Took pictures $81 \mathrm{RB} 0027$

Stop 103

Top of Broad Creek Section. Dike trends $145^{\circ}$

$81 \mathrm{RB} 0028$ ss in $\mathrm{Cg}$. RB $8128 \mathrm{AL}$

Stop $111 \mathrm{~N} 63 \mathrm{E} 26^{\circ} \mathrm{S}$

Long linear ridge $\mathrm{NE}$ of Veniaminoff. Composed of very coarse, poorly sorted, sandstone forms prominant ridge in middle of tundra. Below it may represent a fault scarp because of it's linearity and position. The rocks are highly weathered and fractured.
RB 810029 L Roll 2
$\operatorname{EXP} 26,27,28,29$

2 sets of Joints

$165^{\circ} 65^{\circ} \mathrm{NE}$

$1175^{\circ} \mathrm{SE}$ 
Stop $112 \quad 2$ small hills near Knife Peak

Joint Set $130^{\circ}$

TV $66^{\circ} \mathrm{NW}$

RB $810030 \mathrm{~L}$

Stop 113

$$
\begin{array}{lll}
\mathrm{N} 30^{\circ} \mathrm{E} & \mathrm{N} 25^{\circ} \mathrm{E} \\
& 24^{\circ} & 19^{\circ} \mathrm{AW}
\end{array}
$$

Medium grained poorly sorted tan feldspathic ss. w/1-3 pebble cg. stringers

STR $\quad \mathrm{N} 15^{\circ} \mathrm{E}$

Dip $30^{\circ} \mathrm{SE}$

Stop 114

Observed fault dropping Js against Jn

STRK $N 50^{\circ} \mathrm{E}$

DIP $64^{\circ} \mathrm{SE}$

Wed. $6 / 10 / 81$ Day 12

Sunny, scattered clouds

Stop 121

$\operatorname{STR} 250^{\circ}$

DIP $47^{\circ} \mathrm{NW}$

Intending to walk Blue Violet west w/Tom Dunn

Stop 122

Dunn TD 81104 , TD 81105

Billingsley RB 8131 oil

Approx. 30"-40" petroliferous Chignik, large scale $\mathrm{x}$ beds, weathers tan. Oil stained rock is softer than lower non-petroliferous.

STR $\mathrm{N} 40^{\circ} \mathrm{E}$

Dip $40^{\circ} \mathrm{NW}$ 
Stop 123

STR N55E

Dip $43^{\circ} \mathrm{NW}$

Anomalously short section of Chignik and the Hoodoo took samples $\quad R B 810032 \quad P$ (Paleo)

(Oil stained?) ss RB 810032 L

TD 81106

Thursday, $6 / 11 / 81$

Beautiful weather

Stop 131

Partly cloudy and sunny. Flew into Aniakchak to see Naknek where it outcrops in the Gates. Had hoped to see boulder $\mathrm{cg}$. that scott described. Sand med-grained dirty sandstone $\mathrm{w} / \mathrm{stringers}$ of pebble $\mathrm{cg}$. Across the Gates can see Tolstoi unconformably overlying Naknek.

\section{Stop 132}

Refueled at PDN and left for Broad Creek area. Tom and Mitch made two stops to sample unconf. while I mapped with the helicopter between Broad Creek and Chignik Lake. Finally understood the thrusting mapped by Detterman. Tom took panorama photo from the lunch stop of the Ridge between Boulevard and Fan Creeks.

\section{Friday $6 / 12 / 81$ stop 141}

High angle reverse fault replaces axis of anticline.

Sketch of Ridge line between Naketa Creek and Thompson Valley. Fault extends from Boulevard Creek - to Thompson Valley. I believe Boulevard Creek and Thompson Valley contain detachment faults to explain the offsets across the valleys. Took pictures of the fault.

Stop 142

RB 810033

Stop 143

Paly sample just below contact between Hoodoo and Tolstoi and abv big channel

81 RB 0034? 
Day $156 / 13 / 81$ sat. stop 151

Chignik Bay just north of the bar. Coarse grained light colored Chignik sitting on Jn. Fault in stream bed raises
$\mathrm{Jn}$.

Kc - 8"-10" $x$ beds light colored quartz-feldspathic (lithic arenite) coarse grained to very coarse soft, porous, permeable, friable.

Jn hard, dense dark silt w/clam burrows and warm feeding tracks no buchia observed.

\section{Sunday 6/14-81 stop 161}

Late start because of fog. Started at 8:30.

Revisited Stop 143 to sample Tolstoi sands abv Hoodoo Med - coarse grained volcanogenic sandstone. Green. Again noticed the thick channel sands in the Hoodoo below the contact. Sampled the Tolstoi TD 81 125, 126, 127, 128.

Paly sample at contact between brown and black shales RB 820035 Believe it is stratigraphically abv RB 810034.

Went further down gully towards the contact $w /$ the Hoodoo. Found quartz ss. T.D. thinks these $1 t$ and dk ss may be intercalcated but draining different provenances.

Stop 162

TD $81129 \varnothing \& \mathrm{~K}$

Outcrop of U.Jurassic friable sands between landlocked and Bluff Creeks. Just below contact $w / J R N U$.

Stop 163

STR 227

DIP $24^{\circ} \mathrm{NW}$

Monday $6 / 15 / 81$ Day 17 stop 171

Bearskin Gulch

Mapped as Khc by Detterman. Lt tan med-fine grained friable sands. Very similar to friable pkg that underlies Jnu. These sands are overlain by a dark gray (weathered brown) ss. 
$\mathrm{RB} 810036 \varnothing \& \mathrm{~K}$

$\mathrm{RB} 810036 \mathrm{~L}$ Js?

Stop 172 Revisited Stop 114

STR N $15^{\circ} \mathrm{E} P 14^{\circ} \mathrm{SE}$

RB 810037 P (Buchia rugosa?)

Stop 173

STR $216^{\circ}$ DIP $24^{\circ}$

Coarse grained gray arkose Jn?

stop 174

Apparent anticline is quite confusing. Decided $5^{\circ} \mathrm{N}$ dip is not valid after examining the outcrop. Placed axis of anticline in valley qualitatively. Because of poor condition of outcrops and difficulty of measuring.

Stop 175

Very large fault by Chignik lagoon mapped by wilde and Detterman. Appears near vertical, can't decide if compressional or extensional.

Mitchell \& I both took pictüres.

Also took picture of normal fault up the hill.

\section{Day $18 \quad 6 / 16 / 81$ Front Moving In}

Stop 181

Cloudy, windy near Neketa Creek. Took pictures of ridge Tom and Mitch traversed Day 14.

RB $810038 \varnothing$ from Jks near our location

RB 810038 MP Mega Paleo

Jnu

B. crasscollis?

B. piochi?

Unidentified Pecten, Peleypod.

RB 810038 BLKC Chignik

flaggy $x$ bedded ss weathers olive tan.

No Kc conglomerates observed. 


\section{Stop 182}

Flying west up Parallel crk. and noticed difference in rocks composing the walls of the steep u-shaped valley. The north has lt. and dark Jr W/ a cap of dark. The south has dark slt. and shale w/Buchia (RB 810039 MP). Took picture facing Chignik Lagoon showing dark on right and light on left. Speculate that this valley contains a fault (shear?) but in any case $N($ ?) side is up.

Stop 183

NE side of Thompson Valley sketched in faults 2+ thrusting Jn over Kc as mapped by Detterman.

\section{$\underline{\text { Day } 19}$}

Attempted to resample Bear Lake Tertiary section

RB 41

42 See Columner sect.

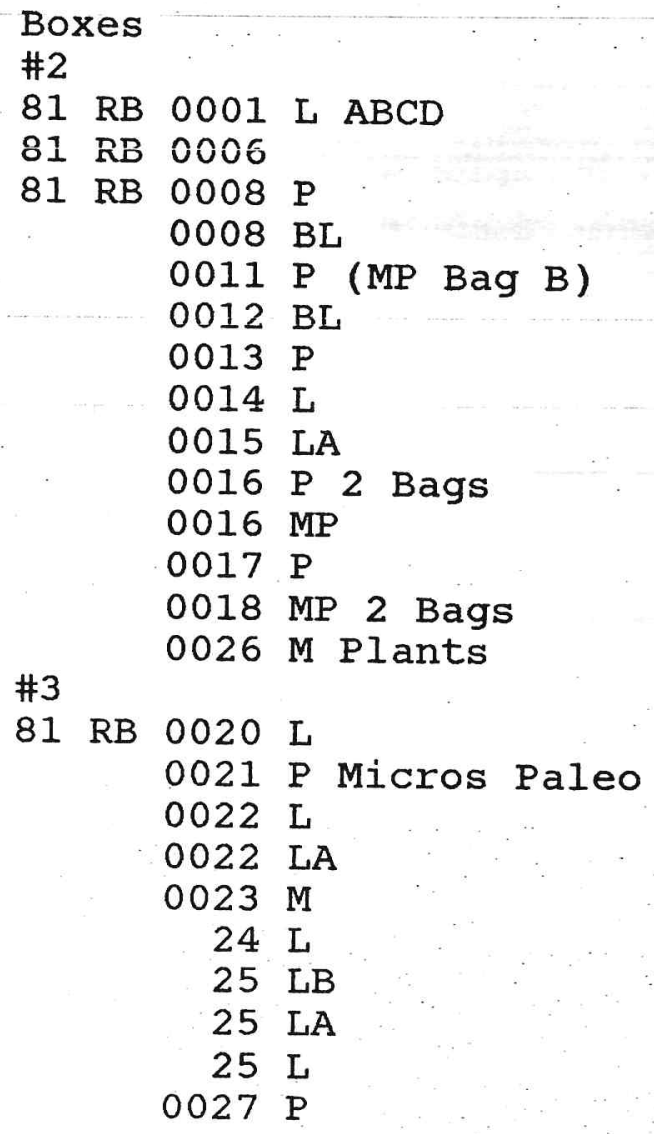

$81 \mathrm{RB} 0020 \mathrm{~L}$

0021 P Micros Paleo

$0022 \mathrm{~L}$

0022 LA

$0023 \mathrm{M}$

$24 \mathrm{~L}$

$25 \mathrm{LB}$

25 LA

$25 \mathrm{~L}$

$0027 \mathrm{P}$ 


$\begin{array}{ll}0028 & \mathrm{DL} \\ 0028 & \mathrm{BL} \\ 0028 & \mathrm{~L} \\ 0029 & \mathrm{~L} \\ 0030 & \mathrm{~L} \\ 0031 & \mathrm{Oil} \\ 0032 & \mathrm{P} \\ 0032 & \mathrm{~L} \\ 0033 & \mathrm{P} \\ 0034 & \mathrm{P}\end{array}$

Day $20 \quad 6 / 18 / 81$

Stop 201

Late start for helicopter adjustments.

Spent day finishing details of Dry Creek - Black Creek Landlocked Creek areas.

Refuel PTH

Flew north over Aniakchak and along trace of Bristol Bay

Fault, some evidence for faulting, not as much as I'd hoped.

stopped at seis camp to notify them of our arrival on Saturday.

Day $21 \quad 6 / 19 / 81$

Weather day, low clouds, rain, fog, no flying.

Day $22 \quad 6 / 20 / 81$

Traveled to Seis camp at Jensen's Strip via Peninsula Airways. Arrived, ate lunch, refueled and went south to Conti's pseudo Jurassic outcrops.

Stop 221 T34S R54W

Low mounds, contain abundant shards of black siltsone $\mathrm{w} /$ Buchia. The question arises as to whether the rocks are in place. Dug pits w/ a pick to discern if solid rock could be found. No solid outcrops could be found. Question remains as to why the mounds are so monolithologic. Rough rounded igneous cobbles were observed. Sample RB 8143 \#1

Took a vote on origin. Mitchell - non glacial - Bob K. glacial-Pilot - Mike - glacial - RB? 
Visited another lump, again, more monolithologic but this time $\tan s \mathbf{w}$ /Buchia. Sample RB 8143 \#2

3rd lump, obviously river gravels, polylithologic rounded clast support, etc.

\section{Day 23}

Partly Cloudy

VABM 1683 Granite

Stop 231 SE of King Salmon

Naknek 1,250,000 T21S R43W

RB $810044 \mathrm{KA}$ K-Argon

RB 810044 G (Gravity)

NW side of the Hill is very steep. Appears likely that the hill represents the $\mathrm{U} / \mathrm{T}$ side of the King Salmon River Fault.

Although the hill is labeled granite, it is composed of Black volcanics (TV?)

Stop 232

VABM 1721 RED

More volcanics. If recollection serves right this is mapped as granite.

Stop 233

$\mathrm{RB} \quad 810045 \mathrm{KA}$

G

Weathered Granite

LJR Avg. coarse grained pink granite

Stop 234

Poorly sorted pebble to boulder $\mathrm{cg}$. Clast supported.

Clasts are well rounded predominately granite but including metamorphics. Mafic volcanics. Thin coarse sand lenses

8-10" thick, color greenish tan.

STR $206^{\circ}$ Dip $43^{\circ}$ ss

Cobble sample for dating

$\mathrm{RB} 80046 \mathrm{KA}$ 
Stop 235

Ugaskik $\mathrm{Cg}$.

Poorly stratified cobble-boulder $\mathrm{cg}$. similar to that seen at 234. Several K-feet of this $\mathrm{cg}$. is exposed to the south.

It is interesting that the $\mathrm{cg}$. seems to dip towards the Bristol Bay fault(?) zone. STR N3OE Dip $40^{\circ} \mathrm{SW}$

Stop 236 Paly RB 810047 P.

Ug Cong

In stream bed 1 cong. in contact w/each other. Uppermost has cobble to boulder sized clasts w/light colored matrix w/hornblend grains lower cong. is darker w/dark matrix (Paly sample).

Day $24 \quad 6 / 22 / 81$

Partly cloudy, wind brisk from the north. Cool 45-50

searching for the reported oil seep, took 2 samples.

Stop 241

\#1 apparent sheen on surface of still water appears fluid at first but cracks like paraffin when the water flows into the can.

\#2 White foam. Forms at edge of lake on lee side, stiff, forms peaks like merangue.

Stop 242

Grab water sample of sheen from marshy area.

Paraffin type sheen on surface of water very boggy, stagnant area. Much dead plant material rotten smell, $\mathrm{H}_{2} \mathrm{~S}$ ?

Went to king salmon for mail and lunch.

After return we searched for visible evidence of faults in the vicinity of Becharof to Egegik. We were basically unsuccessful. The terrain does not lend itself to geomorphic analysis because of irregularity. Sampled $\mathrm{H}_{2} \mathrm{O}$ w/sheen near Egegik. 
Stop 243

Sample \#4

Refuel, off at 2:00 p.m.

To investigate Pearl Creek Dome.

Prowled the abandoned oil camp for awhile, then investigated the "nonmarine Jurassic section" in the gates of Mt. Peulik.

Stop 244

Gates of Mt. Peulik. Tan sandstones med-coarse grained arkoses angular to sub-angular gray bentonites and

claystones. Gray pebble to cobble cg.

The most startling thing of interest is the friability of the sands. They are generally even more friable than the $U$ JR sands of Chignik Anticline. We are having great difficulties even getting pieces to run porosity because they fall apart.

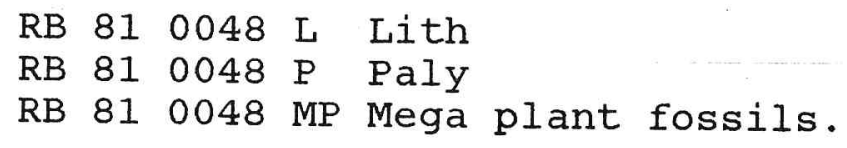

Coalified plant remains are also found, however, they may not be identifiable.

\section{Tuesday $6 / 23 / 81$ Day 25}

Cloudy, low ceiling, cold, windy.

Stop 251

More Creek

Strange outcrop

3 dominant lithologies

1) Large scale channels and beds, grey, friable coarse grained, poorly rounded arkose (reminds Kemp of Granite Wash) sheared and fractured, weathers spheroidally. Contains clasts of granite and grey siltstone.

RB 0049 L

2) Cobble to boulder cg. coarse grained matrix seems to be a channel lag eroding on gray siltstone. Cg. contains rounded clasts of Granite, siltstone. Well indurated. 
3) Dark gray, fine grained siltstone (Jr?) oldest unit present highly fractured, well undurated. No obvious bedding.

Stop 252

Thick bedded boulder cg. predominately granite clasts, clasts to $1^{\prime}$ in diameter. No sed structures obvd. Age?

Stop 253

Very large mafic dike strikes $74^{\circ}$ seems vertical $20^{\prime}-30^{\prime}$ thick lies next to a narrow valley which may be a trace of the Bristol Bay fault.

Sample RB $0050 \mathrm{KA}$

Wed. $6 / 24 / 81$ Day 26

King Salmon to pick fish and wildlife for trip to Puale Bay. Called Karen and McKeever.

Stop 262

Walking beach looking for oil stained sands reported by others. Unsuccessful so far. Bob has found an organic (?) rich layer. We're sampling the layer for Vitrinite and Paly.

RB $0051 \quad V \& P$

Dark gray pebble cg. at base of white ss cliff.

261 sampled med. gr. sandstone on point large scale $\mathrm{x}$ beds

RB 810052 L

Did not find oil stained ss. Must call McCoy to see if he knows its location.

Day 27 June 25,1981

Bright sun, windy, brisk.

Stop 271

Vicinity of Mt. Peulik traversing section of JR sands, and cg. Nonmarine no Buchia found so far. Sands are tan, immature arkoses, differential cementation causes some to form bluffs others to weather friable. 
Cg. are cobble to boulder size lenses usually several ft. thick. Contain granite metamorphic, metasediments sub angular - sub rounded clasts, matrix is coarse grained tight sands. Clasts weather out and cover ground.

Some sands exhibit dark staining (oil?) and seem softer than others.

$$
\begin{aligned}
& \text { RB } 0053 \text { OIL (?) } \\
& \text { STR } 324^{\circ} \\
& \text { DIP } 5^{\circ} \mathrm{NE}
\end{aligned}
$$

Stop 273

Hills near Ugashik Lake.

Tops of hills covered with light colored arkosic sandstone probably Jrs. Walked towards the edge of the lake; soon the hills were covered with clasts of granite and meta seds suggesting that we were in conglomerates.

\section{Stop 274}

Landed on knoll and climbed down to sample the rocks at the lake edge for paly.

At the lake edge the rocks were hard, dense grayish green siltstone, highly fractured, with some plant debris. Appeared to be Jn.

$$
\begin{array}{llll}
\text { RB } & 0055 & \text { MP mega plants } \\
\text { RB } & 0055 & P & \text { Paly sample }
\end{array}
$$

Strike and dip in Mitch's book STK $176^{\circ}$ D-39NE

Stop 275

Rocks appear Jr

Green silts and sands, hard, highly fractured, no fossils.

\section{Day $28 \quad 6 / 26 / 81$}

Partly cloudy, gentle breeze, cool.

Stop 281

East side of U.Ugasik Lake outcrop of Eocene (Phillips

Paly) sheared highly fractured poorly indurated silts and 
shales. Plant fragments (deciduous) coalified tree trunks in float. Much, much softer than other shales in $\mathrm{cg}$. to $\mathrm{N}$. That these rocks date as Eocene is quite believable. If these rocks are Eocene it is hard to believe the $\mathrm{cg}^{\prime} \mathrm{s}$ are so hard if they're only Miocene.

Outcrop is tan with streaks of gray clay rich intervals.

Kemp says abundant bentonite.

RB 810056 P Palynology

RB 810056 MP Megaplant

Around the corner we found pebble cobble cong. w/high angle crossbeds.

The cobble size in this cg. is much smaller than that in the higher hills. Well rounded clasts of granite and meta seds, mafics.

\section{Stop 282 Ugashik $\mathrm{Cg}$.}

Getting very suspicious that the Ugashik $\mathrm{Cg}$. is really $\mathrm{Jn}$. Took paly sample ( $R B 820057 \mathrm{P}$ ) from this black silt at bottom of crossbedded channel sand. Sand was 10-15' thick erosional base and scoured on top. Composed of quartz, feldspar w/biotite flakes. Well indurated.

Rough landing $\mathrm{w} /$ helicopter on ridge top. Down draft hit us at last minute. Potential overtorque of drive tran. Flew immediately to camp so Calvin and Mike could check it out. No overtorque so we took recon flight towards Wide Bay and then south towards Mt. Chiginagak. Saw Amoco Spa. Returned towards camp intending to make some more stops on the Ug. cong. but was too windy to land.

Day $29 \quad 6 / 27 / 81$

Left for Chignik area to clean up some details.

Refueled at Port Heiden and headed for Black Lake area. Decided Jrs was not present just $\mathrm{N}$ of Chignik Lake. Took Bob on tour to see some of the more spectacular outcrops, and went to Aniakchak River to look for seep reported by BLM via McKeever. Did not find seep, but salmon were running. Fished for a little while and then long flight home. 
Day $30 \quad 6 / 28 / 81$

Bad weather, low ceiling, fog, rain.

Lifted a little after noon.

We tried to get into Mother Goose Lake area but ceiling

lower down there. Grabbed some Buchia rich tan sands for $\varnothing$ $\& \mathrm{~K}$, paleo and lith.

RB $810058 \varnothing$

RB $810058 \quad \mathrm{P}$

RB $810058 \quad$ L

Box \#4

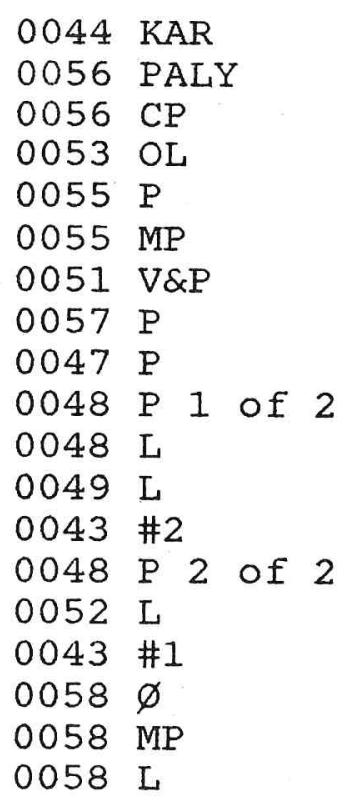

Box \#5

$0048 \mathrm{~L}$

$0046 \mathrm{~K}-\mathrm{Ar}$

$0050 \mathrm{~K}-\mathrm{Ar}$

2 Jr?

$0044 \mathrm{G}$

$0045 \mathrm{G}$

$0045 \mathrm{~K}-\mathrm{Ar}$ 
Final Day?

List

Car and Hotel reservations. Sample Meshik for gravity.

Sample Gas Rocks and Peulik. Resample paly locations, chk for $\mathrm{Jn}$ on lake below Peulik and contrast between nonmarine and marine.

Sample Mother Goose Lake sections.

Check shore of Ug Lake for Jr. mega fossils.

Accomplishments :

Sampled glacial outcrops - looked at Ug. cong.

Looked for surface fault

Looked for JR oil stains, sand seeps - unsuccessful or in wilderness.

5005 U Test

5004 Lwr Plio int 2

5003 U Test

5002 U Mio? Int 2 or 3

5006 Barren

1007 No info

1097 Barren

1101 Lower Plio int 2

Sent Mitch to get gravity sample of Meshik fm.

RB 820059 G

Day $31 \quad 6 / 30 / 81$

Back in the field after Bob's little mishap. Vicinity of Dog Salmon R.

Stop 312

Ugashik Cg. above Dog Salmon R. Less indurated than in other places. Easier to believe its Tertiary. Cobble to boulder cong. with outcrops of coarse to $v$ crs sand. Clasts are sub rounded to well rounded. Fine sand interbeds are $\mathrm{x}$ bedded.

Sand interbeds are almost friable and look dark? Oil maybe. Samples 


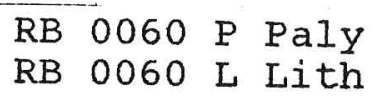

$\underline{313}$

Island in L.Ugashik Lake. Ugashik Cg. Granite cong. cobble to boulder subrounded to rounded clasts. Med to coarse matrix. Scour features, heavy mineral separations. Fine layers are $x$ bedded with dark banding. Coarser matrix looks like a sedimentary granite.

Try for Paly RB $810061 \mathrm{P}$ Lith RB 810061 L

314

Just $N$. of Ugashik. Narrows near BB Fault. U/T side punky, $x$ bedded dark mafic ss stringers of pebbles.

RB 0062 P\&L

$\mathrm{RB} / \mathrm{mIm}$

RTP509

101582 
Will be provided by

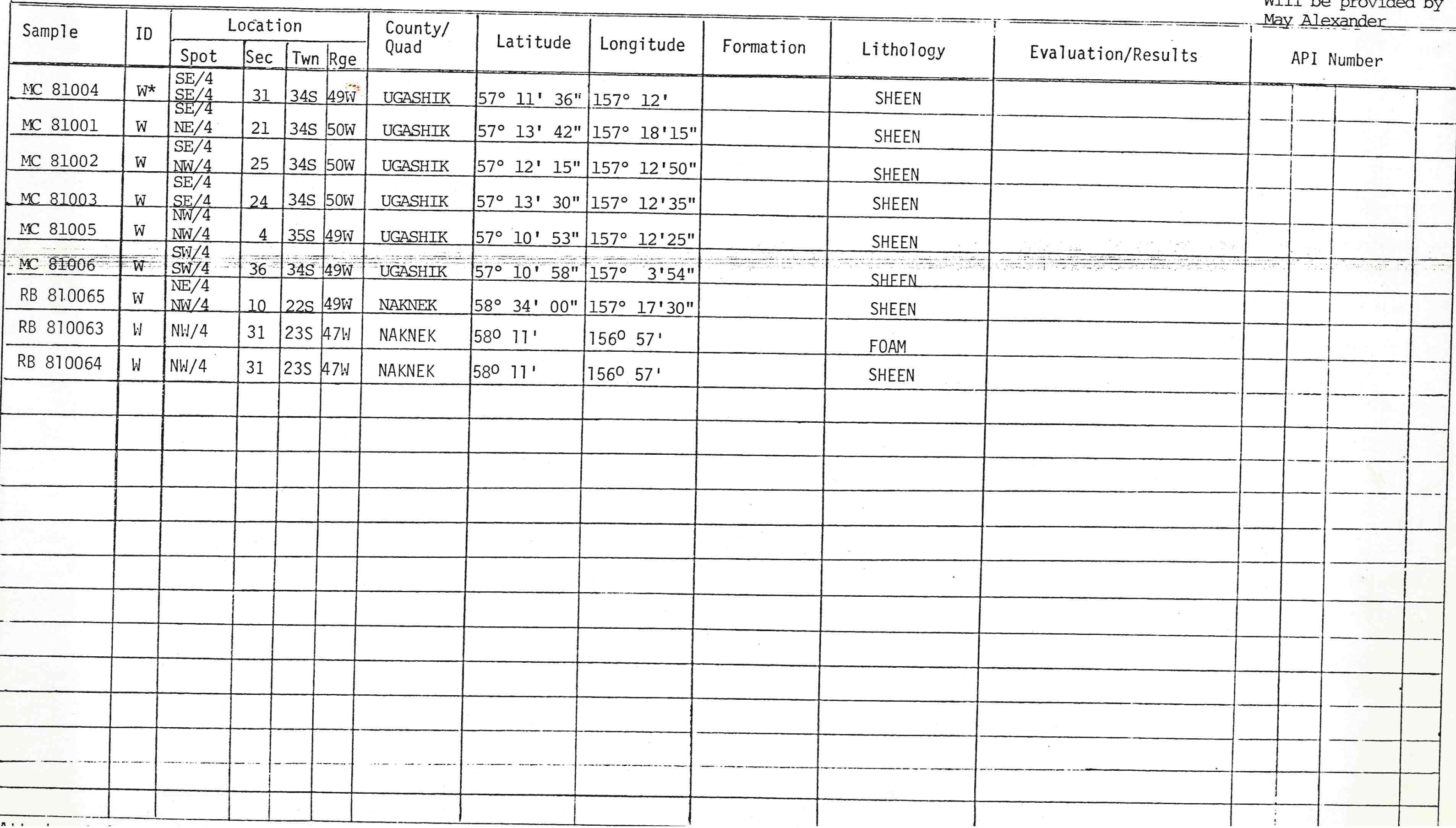




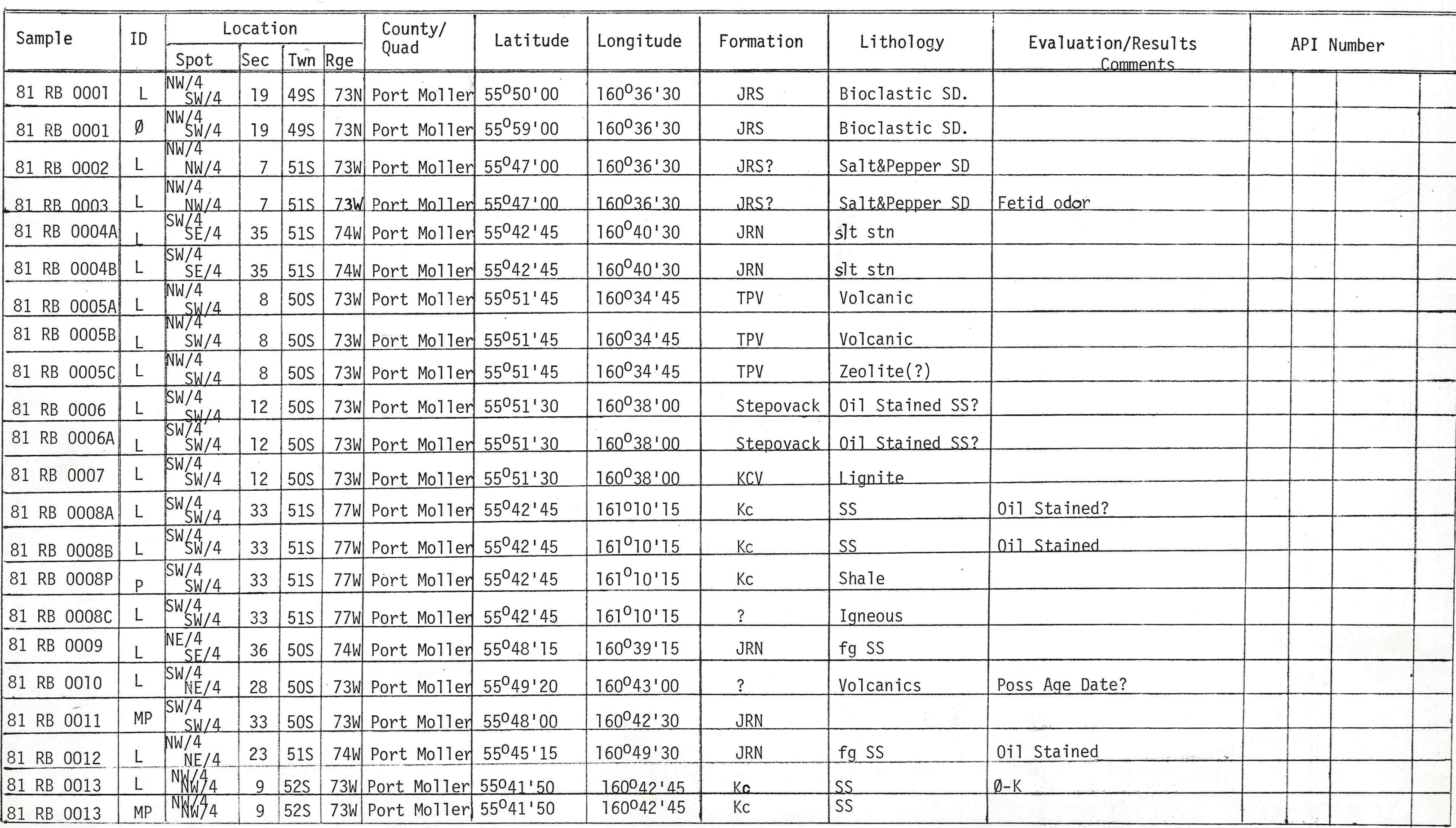




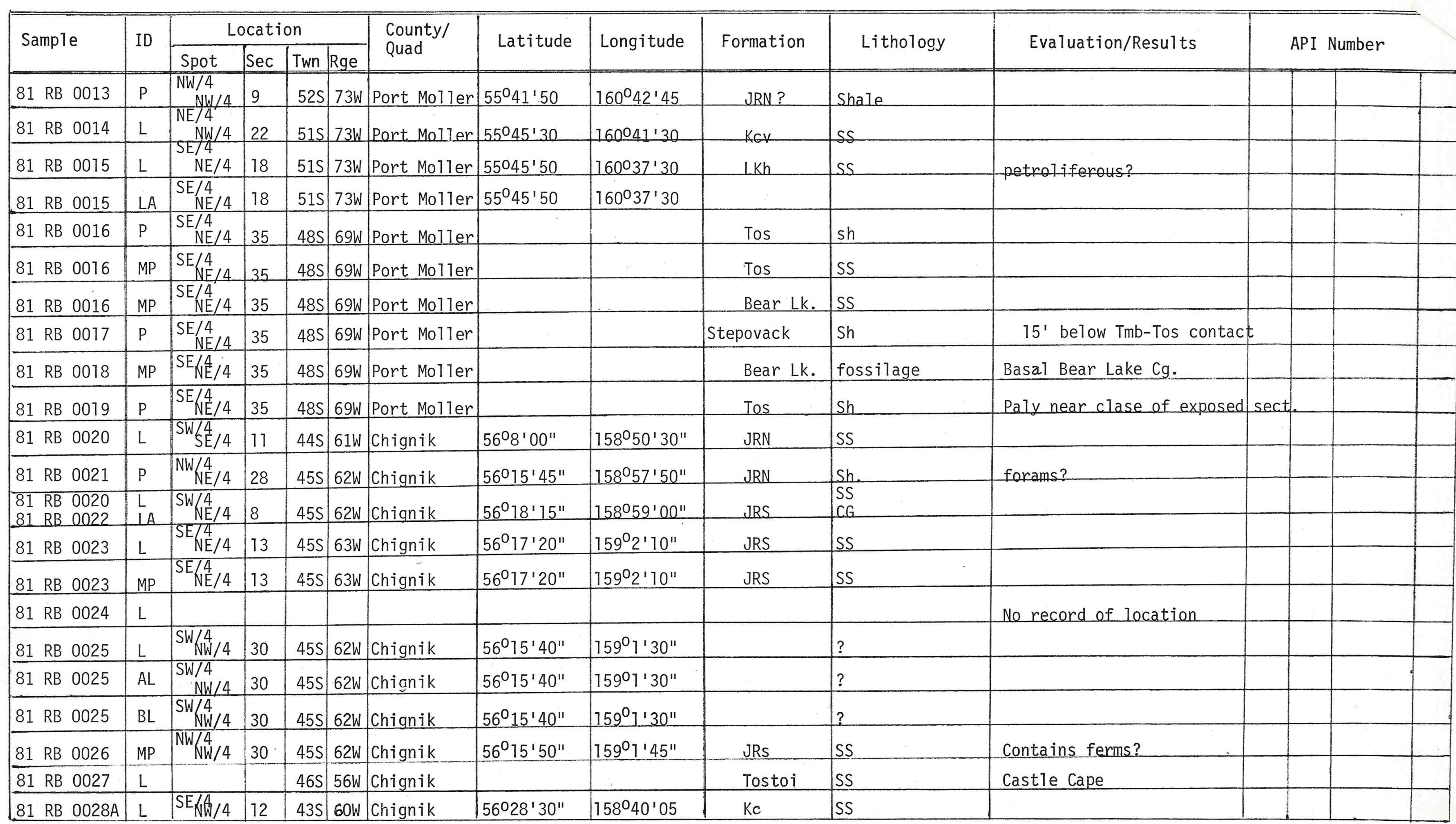




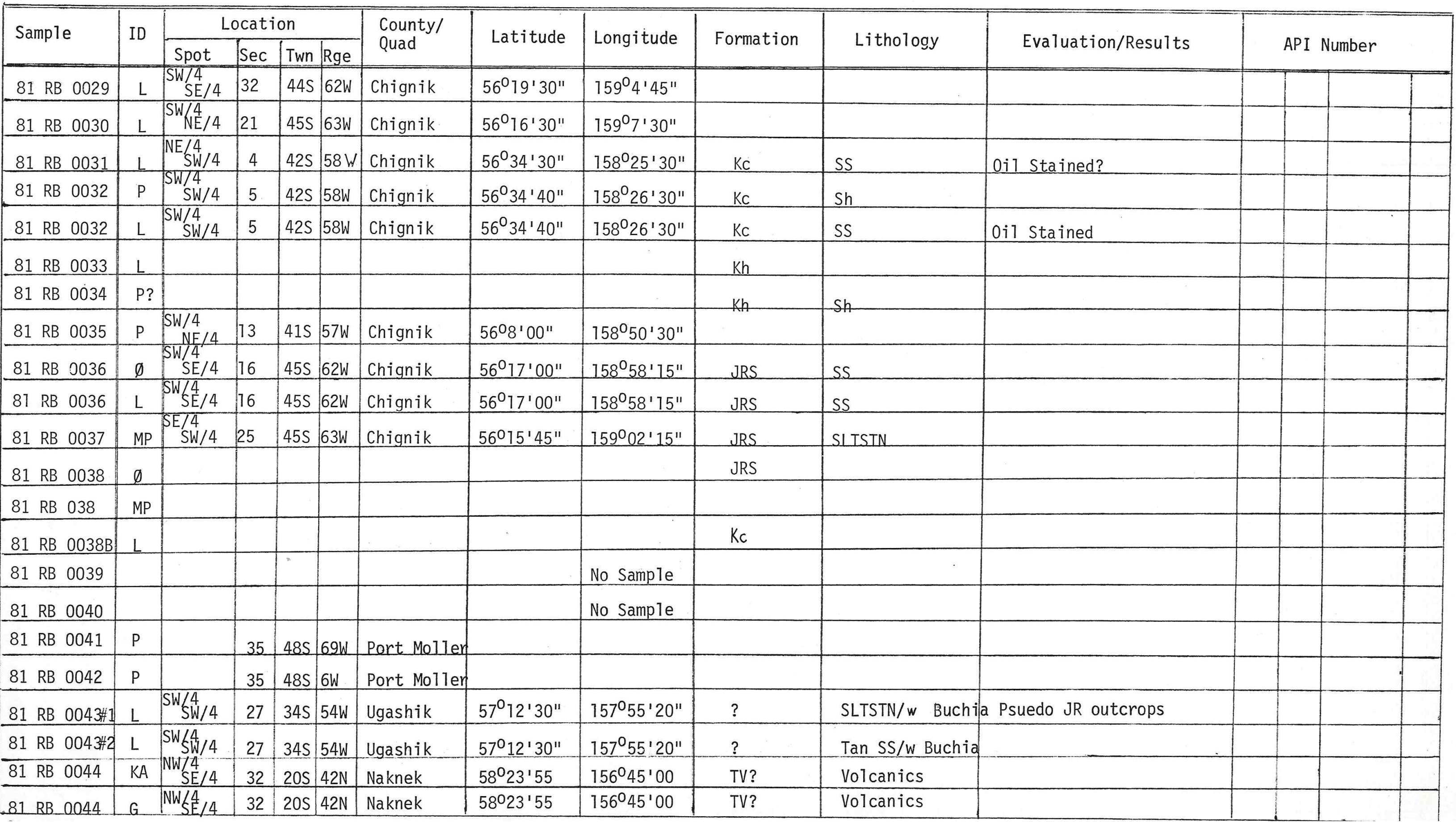




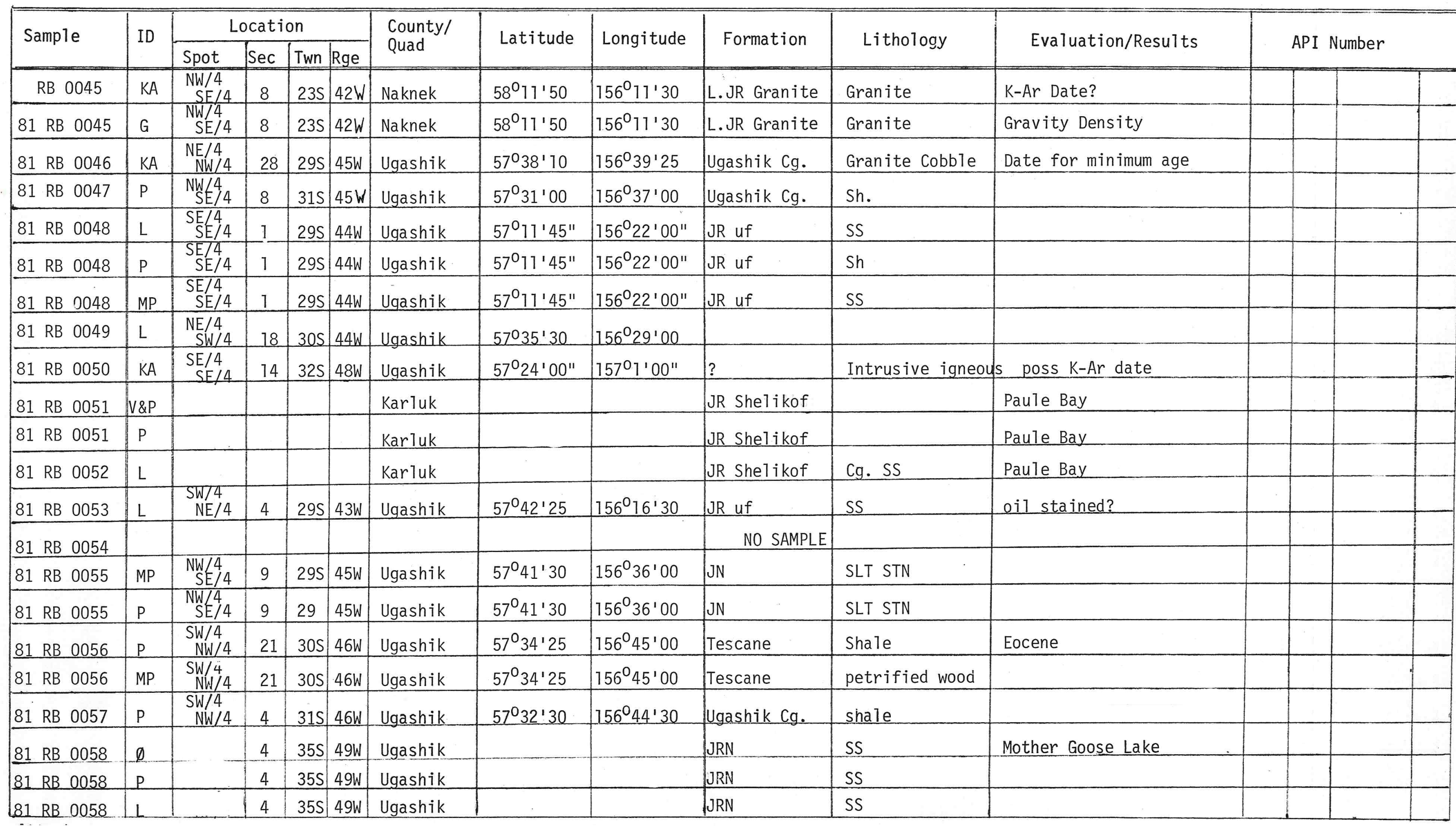




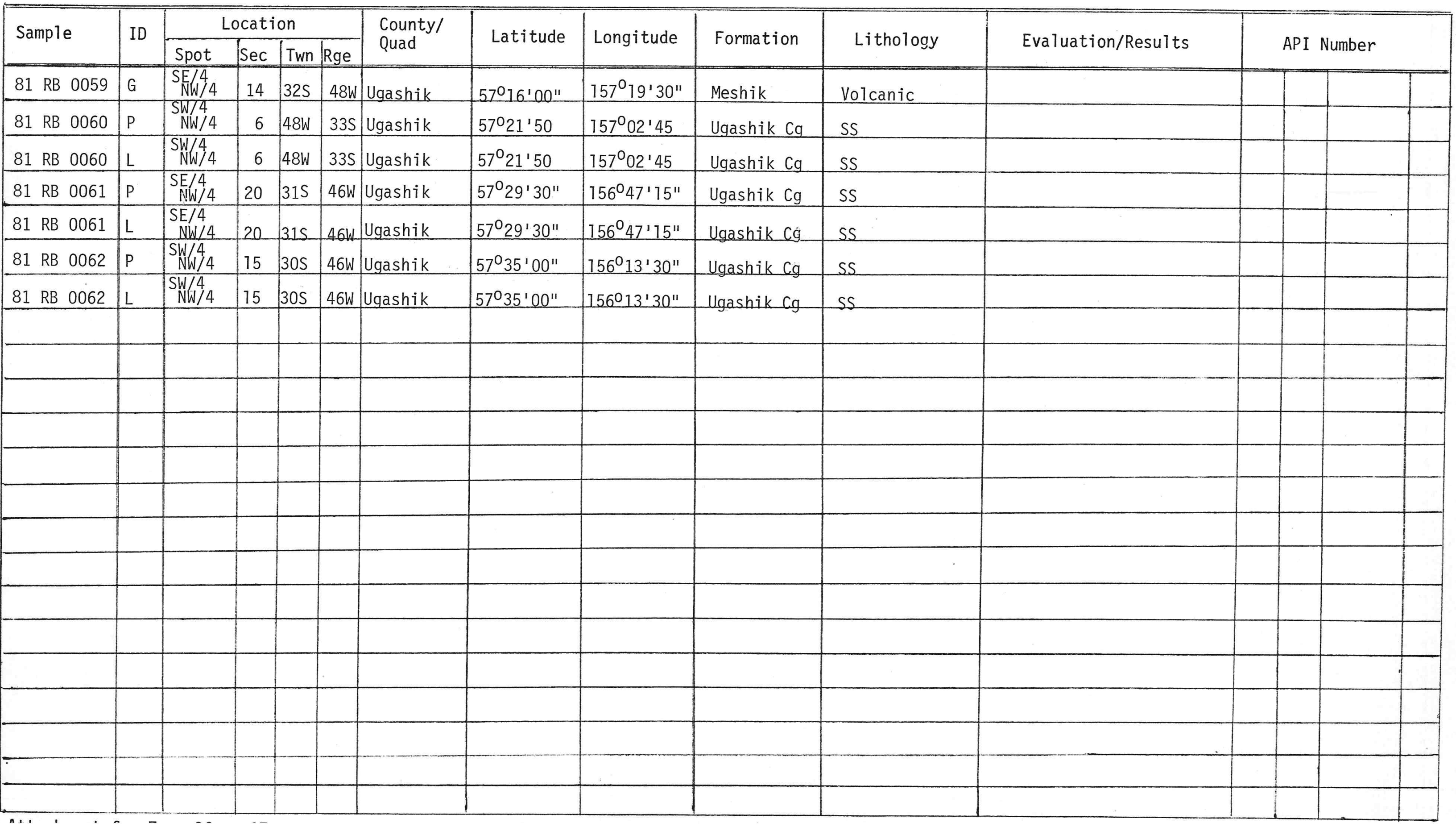




\section{Amoco Production Company
Denver, Colorado}

August 10, 1981

Jim Parks

BUILDING

Evaluation of the Alaska Peninsula data base during the past year has revealed a number of inconsistencies in age dating of outcrop and we11 data. This body of data spans some 14 years and several workers, thus it is not surprising that inconsistencies exist. The resolution of these problems and the establishment of a regional palynologic framework is of vital importance to our future efforts in this area.

The establishment of such a framework now is especially timely in light of the upcoming C.O.S.T. program and lease sales in the Bering Sea area. The offshore areas are geologically similar to the Alaska Peninsula and proper interpretation and evaluation of the C.O.S.T. wells requires a regional palynologic framework which does not presently exist.

The establishment of a regional palynologic framework for southwestern Alaska is needed and timely. Please institute this project.

G. I. Lindahl 
August 26, 1981

W. G. Brock

$2302 A B$

ATTN: R. Billingsley

PALYNOLOGICAL ANALYSIS OF 10 SAMPLES FROM THE 1981 BBNC

FIELD PROGRAM

\begin{tabular}{|c|c|c|c|}
\hline $81 \mathrm{RB} 0035$ & Stop 161 & $13-41 S-57 W$ & $\begin{array}{l}\text { Recovery moderate; Paleogene } \\
\text { age (probably Eocene) }\end{array}$ \\
\hline 81RB0047 & Stop 236 & $8-31 S-45 W$ & Barren \\
\hline $81 R B 0048$ & Stop 244 & $1-29 S-r r W$ & $\begin{array}{l}\text { Recovery moderate; probable } \\
\text { Upper Jurassic age (based on } \\
\text { palynology and megaplant remains) }\end{array}$ \\
\hline $81 R B 0055$ & Stop 274 & $9-29 S-45 W$ & No Recovery \\
\hline 81RB0056 & Stop 281 & $21-30 S-46 W$ & $\begin{array}{l}\text { Barren; age probably Eocene } \\
\text { (based on leaves and wood) }\end{array}$ \\
\hline $81 R B 0056 C$ & Stop 281 & $27-30 S-46 W$ & $\begin{array}{l}\text { Recovery not age diagnostic } \\
\text { (cuticle and wood fragments) }\end{array}$ \\
\hline 81RB0057 & Stop 282 & $4-31 S-46 W$ & Barren \\
\hline 81 RB0060 & Stop 312 & $6-33 S-48 W$ & No Recovery \\
\hline 81 RB0061 & Stop 313 & $20-375-46 \mathrm{~W}$ & Barren \\
\hline 81RB0062 & Stop 314 & $15-30 S-46 W$ & Barren \\
\hline \multicolumn{4}{|c|}{$\begin{array}{l}\text { W. Bayundale } \\
\text { W. Baxendale }\end{array}$} \\
\hline
\end{tabular}


August 10, 1981

W. G. Brock

$2302 A B$

ATTN: R. Billingsley

PALYNOLOGICAL REANALYSIS OF 13 SAMPLES FROM THE 1968 AND 1970 ALASKA PENINSULA COLLECTIONS

As requested, I have reexamined these samples with relative age determinations as the objective, as follows:

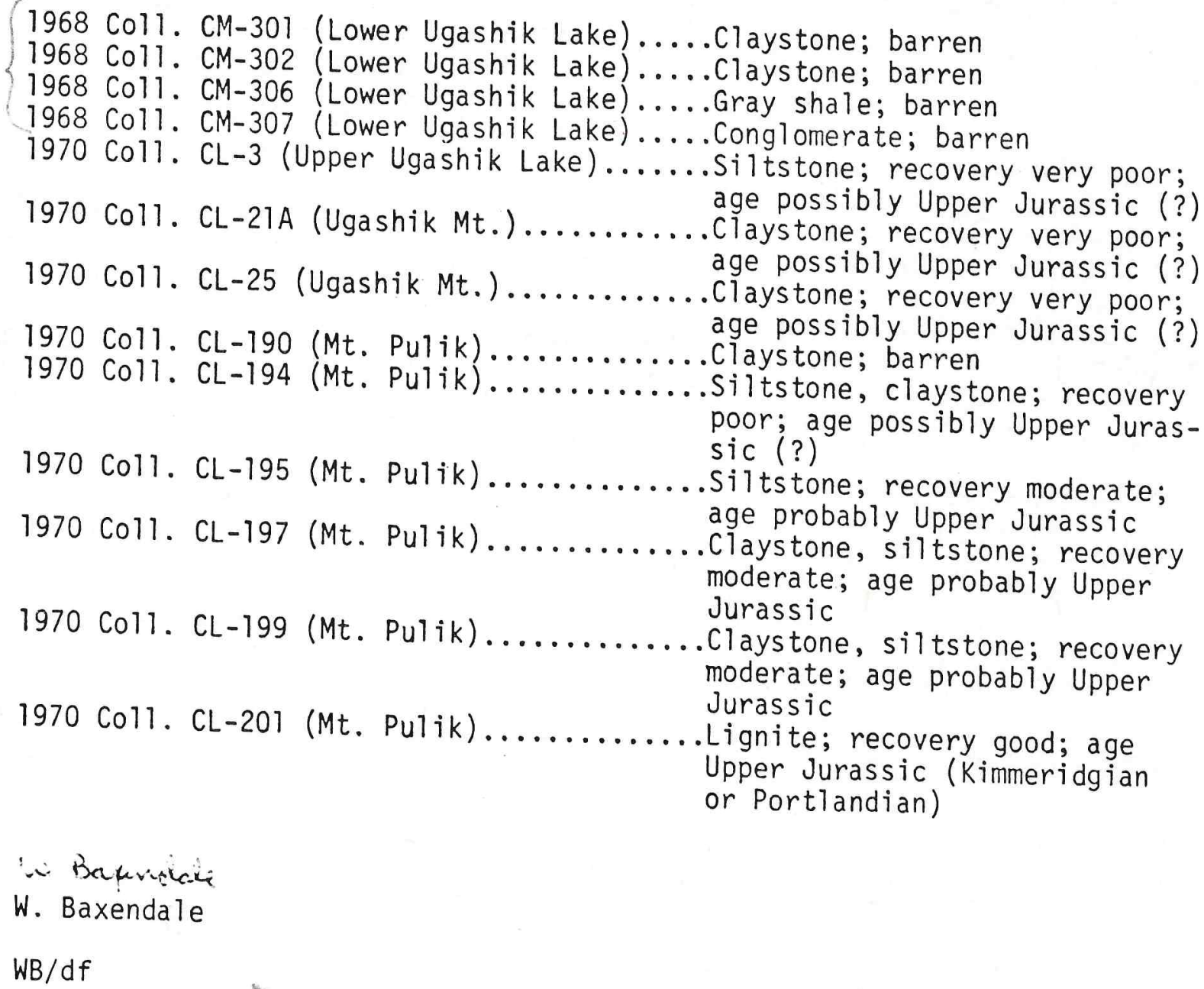


JuTy 30,1981

W. G. Brock

$2302 \mathrm{AB}$

ATTN: R. Billingsley

PALYNOLOGICAL REANALYSIS OF 14 SAMPLES FROM THE 1977

AND 1978 ALASKA PENINSULA OUTCROP COLLECTIONS

As requested, I have reexamined these samples using revised Composite Standard values. Special emphas is was placed on eliminating out of place material from the relative age determinations.

1977 Col1. $1023(25-55 S-78 W)$ :

1977 Co11. $1027(18-54 S-75 W):$

1978 Col1. $1093(22-36 S-52 W):$

1978 Col1. 1094 (22-36S-52W):

1978 Coll. $1097(28,29,30-32 S-47 W)$

1978 Coll. $1098(28,29,30-32 S-47 W)$ :

1978 Col1. $1099(28,29,30-32 S-47 W)$ :

1978 Col1. $1100(28,29,30-325-47 W)$ :

1978 Col1. $1101(28,29,30-32 S-47 W)$ :

1978 Col1. 1147 (2-18S-71W):

1978 Co11. 1196 (7-18S-60W):

1978 Col1. 1197 (35-20S-59W):
Shale; recovery good; age probably Eocene with abundant Neogene (Miocene?) taxa present but here considered out of place.

Shale; same information as for sample no. 1023.

Gray siltstone; barren

Gray siltstone; recovery very good; age probably Eocene with upper Tertiary forms out of place.

Coarse sandstone; barren.

Sandy siltstone; barren.

Gray siltstone; barren.

Gray sandy siltstone; barren.

Green-gray sandstone; barren (recovery poor and apparently out of place)

Gray siltstone; recovery good; age Neogene (Upper Miocene?)

Gray claystone; recovery good; age Neogene (Lower Pliocene?)

Gray claystone; recovery good; age Neogene (Lower Pliocene?) 
Page Two

1978 Co11. $1198(12-19 S-58 W)$ :

Gray claystone; recovery good; age Neogene (Lower Pliocene?).

1978 Col1. $1199(3-18 S-58 W)$ :

Gray claystone; recovery good; age Neogene (Upper Miocene?).

W. Eapudate

W. Baxendale

$W B / d f$ 
July 14,1981

W. G. Brock

$2302 \mathrm{AB}$

ATTN: R. Billingsley

PALYNOLOGICAL REANALYSIS OF 8 SAMPLES FROM THE 1978 BRISTOL BAY OUTCROP COLLECTION

As requested, I have reexamined these samples using new fungal palynomorph data and revised Composite Standard values, as follows:

B78-2013 (5-53S-80W) : Recovery excellent; probable middle or upper Eocene age.

B78-5001 (10-47S063W): Abundant dinoflatellates; two possible interpretations:

1. If the dinoflagellates are in place, the sample upper Jurassic (Callovian or Oxfordian)

2. If the dinoflatellates are reworked the sample is of unknown age but presumable Tertiary (?).

These two possibilities seem about equal in probability at this point.

B78-5002 (3-33S-48W): Recovery poor; age Tertiary (probably middle or lower).

B78-5003 (34-30S-46W): Recovery poor; age Tertiary.

B78-5004 (15-30S-46W): Recovery excellent; probable middle or upper Eocene age.

B78-5005 (9-29S-45W): Recovery poor; age Tertiary (probably middle or lower).

B78-5006 (22-33S-49W): Recovery very poor; age probably Tertiary.

B 78-5007 (4-34S-49W): No recovery; age indeterminate.

W. Daphenclale

W. Baxendale,

$\mathrm{WB} / \mathrm{df}$ 
December 11, 1981

W. G. Brock

$2302 A B$

ATTN: R. Billingsley

PALYNOLOGICAL ANALYSIS OF 3 SAMPLES FROM THE

1968 ALASKA PENINSULA COLLECTION

$\begin{array}{lrll}\text { CM68 } & 323 & \text { Sandstone } & \text { Barren } \\ \text { CM68 } & 330 & \text { Claystone } & \text { Recovery not age diagnostic* } \\ \text { CM68 } & 332 & \text { Claystone } & \text { Recovery not age diagnostic* }\end{array}$

* This catagory includes such materials as wood fragments, most cuticle pieces, most fungal hyphae, pollen/spore grains that could as well be Mesozoic as Cenozoic, are out of place through cave or rework, or are too badly degraded to be identified with certainty.
w Bapuntaces
W. Baxendale
$W B / d f$ 
Helicopter \& Fuel

ERA Hel icopters Inc.

Chevron (Jet fue1)

Troy Air (Transportation of fuel)

TOTAL $\$ 46,894.93$

Crew Moves

Troy Air (Anch. to Pt. Moller)

Kenai Flying Service (Pt. Moller-Pt.

Peninsula Air Service (Pt. Heiden-

Mile Hi Geophysical (Jensen's-King

$\$ 42,452.35$

$1,103.58$

$3,3.39 .00$

$\$ 46,894.93$

Salir..n)

\author{
$\$ 4,940.00$ \\ 862.00 \\ 850.00 \\ $\$ 6,652.00$
}

Accommodations

Bear Lake Lodge

Pt. Heider

Jensen's strip

$\$ 4,625.00$

$5,275.00$

$\$ 9,900.00$

Air Freinht:

Pt. Heiden

Kina Salmon

$\$ \quad 177.36$

Anchorade

39.56

200.83

418.30

Commercial Airfares

Den - Anch - Den/a neople

Kina Salmon - Anch/3 rople

$\$ 2,973.32$

240.09

273.10

$3,486.32$

Misc. expense

R.L. Billingsley

$\$ 1,613.09$

$\$ 68,964.64$

* Durinc this period, the Geolonical Field narty stayed at the Mile $\mathrm{Hi}$ geophys cal camn under contract to Amoco. Costs for fuel, lodaing and crew moves werf: absorhed by the neophysical proaram 
AMOCO PRODUCTION COMPANY

Tulsa, Oklahoma

November 23, 1981

FILE: $\quad$ Technical Service 9528WX

TO: G. Lindah1, Denver - Far West

ATTN: $\quad$ R. L. Billingsley

SUBJECT: Bentol Analysis of Surface Water Samples (API Nos.

502859980008-502859980013 and 501859980000-501859980002)

Gas chromatographic analysis of the surface water samples forwarded showed neither benzene nor toluene. In addition, no other hydrocarbons were found in significant quantities. A copy of your attachment to Form 97 is enclosed.

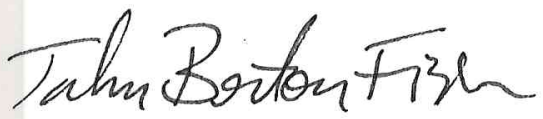

J. B. Fisher

$\mathrm{JBF}: 1 \mathrm{mw}$

Enclosure

cc: C. Goranson

R. R. Thompson/E. R. Michaelis

H. D. Winland 
BBNC 1981 Field Program

Project

Will be provided by

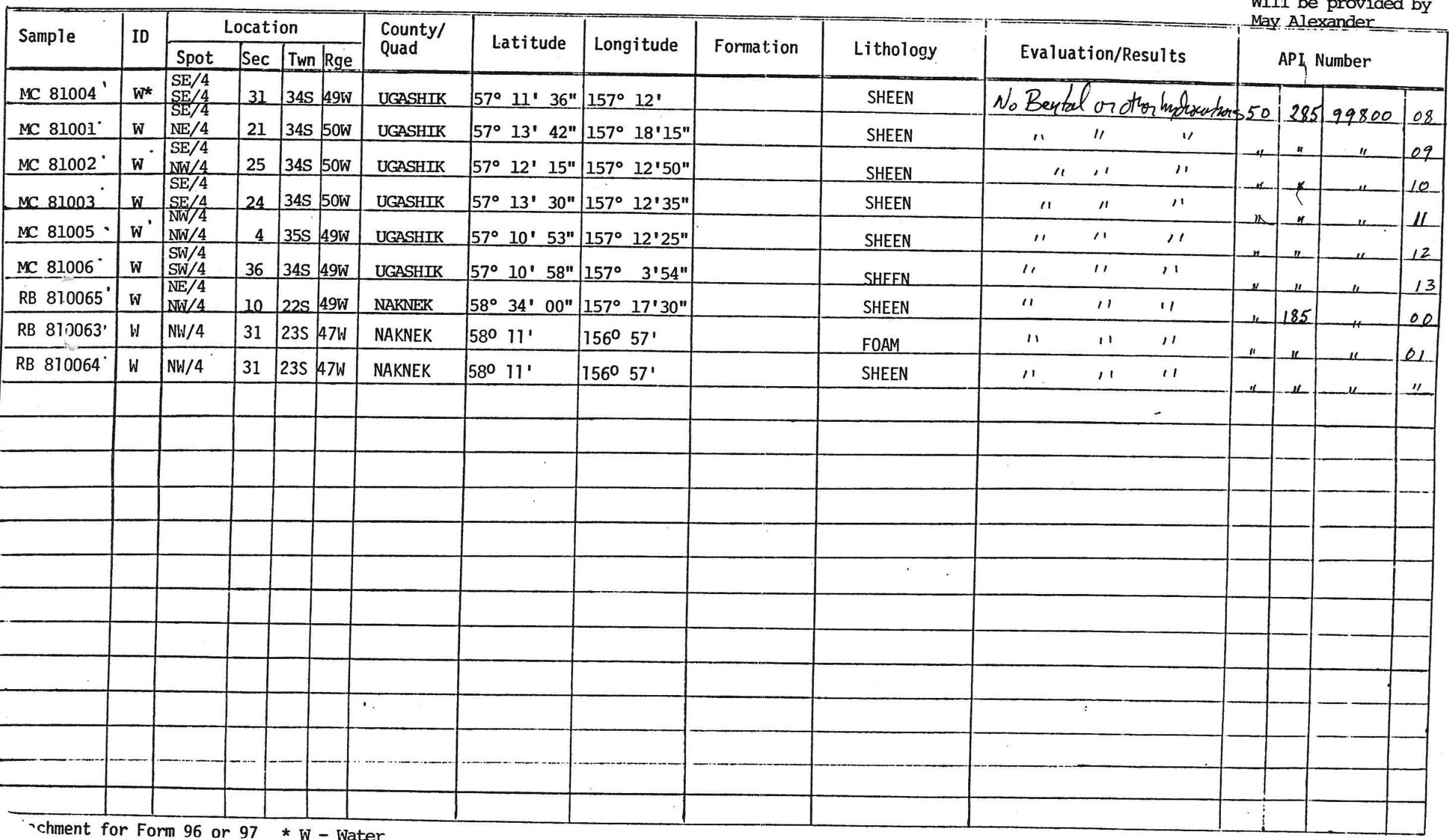




\section{FILE: $\quad$ Techıical Service 819293SX}

TO:

$$
\text { W. G. Brock, APC (USA) Denver }
$$

SUBJECT: Preliminary Report on Field Work on the Alaska Peninsula, Chignik Anticline Area: Evaluation of Reservoir Potential of the Jurassic and Cretaceous Sandstones

At your request I accompanied geologist $\mathrm{R}$. Billingsley in field work in the Chignik Anticline Area, Alaska Peninsula for the purpose of evaluating reservoir potential in Jurassic and Cretaceous sandstones. Approximately six (6) days was spent sampling and familiarizing myself with the geology of the area. We tried to key in on two areas of study:

1. We collected paired samples wherever it was possible to recognize sandstones which showed evidence of the presence of hydrocarbons; i.e., actual seeps, brown staining, or those sands which gave a sulfurous or petroliferous odor from a freshly broken surface.

2. We attempted to sample along unconformities in sands above and below the major erosional contacts in pursuit of potential secondary porosity development associated with such horizons.

\section{PRELIMINARY RESULTS}

I collected 29 samples of sandstones from four formations:

\section{Formation}

Tolstoi
Hoodoo
Chignik
Naknek

Paleogene Upper Cretaceous Upper Cretaceous Upper Jurassic/Lower Cretaceous

$$
\begin{aligned}
6 & \text { samples } \\
1 & \text { sample } \\
14 & \text { samples } \\
8 & \text { samples }
\end{aligned}
$$

R. Billingsley and other coworkers are collecting samples of selected units. The number of samples to be initially included in the analyses is anticipated to reach 40 to 50 . 


\section{COMMENTS}

1. At least four sample sets of petroliferous sands have been collected (two from the Chignik, one from the Staniukovich, and one from the Stepovak). These samples will be useful in determining relative timing of petroleum migration to diagenesis.

2. The most porous and permeable units encountered were the white friable sandstones of the Naknek and the overlying buff sandstones of the basal Chignik formation.

3. Concretionary or "tight streaks" are common within these sandstones. These rocks form prominent outcrops, retain bedding features, and hence are preferential sampling sites. However, they are commonly tight. The more porous, less cemented sands weather friable and form saddles and low sags along the ridgelines. Sampling of the more porous sands commonly takes on the form of minor digging, excavation, or picking up float. Consequently, primary sedimentary structures are obscured. This relation of wellcemented outcrops and more porous sands found in low spots was consistent throughout the field area. In most cases we sampled both the friable as well as the well-cemented (predominantly carbonate) sandstones.

4. Of curious note is a white to light buff, lithic-poor coarse to medium-grained $1-10 \mathrm{~m}$ thick arkose which tops the Cretaceous Hoodoo formation. The unit is continuous for several miles along the northern flank of the Chignik Anticline. The Paleogene Tolstoi which overlies the Hoodoo is characterized by its strong volcaniclastic component. This intercalated quartz-rich sand is indicative of diverse and localized provenance resulting in perhaps equally diverse diagenesis and reservoir potential.

5. It was our intention to look critically at the alteration of Naknek sandstones along overlying Cretaceous unconformities. Where this erosional feature is well-exposed, the Naknek is characteristically comprised of well-cemented very fine-grained sandstone and siltstones. In some areas, the fine-grained Naknek is pervasively sheared and annealed with a feldspar or zeolite cement. These units are thought to be poor candidates for reservoirs and were not systematically sampled. However, where coarser sands were adjacent to the Cretaceous unconformity, they were sampled.

6. R. Billingsley and S. McCoy have made sample logs and maps showing sampling locations from previous years available to me. Selected samples from our previous locations will likely be utilized in this current study. 


\section{ANALYSES}

At the time of the drafting of this memorandum, the samples were still in transit. Petrographic analyses, porosity and permeability measurements and X-ray diffractometry will be performed on the samples when they become available.

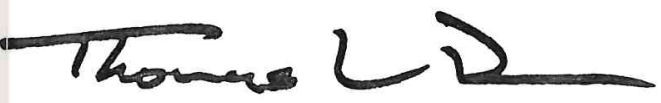

Thomas L. Dunn

TLD : ch

cc: R. Billingsley, APC (USA) Denver

G. I. Lindah1, APC (USA) Denver

S. McCoy, APC (USA) Denver

R. R. Thompson

H. D. Winland 